University of Montana

ScholarWorks at University of Montana

7-19-2007

\title{
Analysis of Flow Competence in an Alluvial Gravel Bed Stream, Dupuyer Creek, Montana
}

Andrew C. Whitaker

Donald F. Potts

University of Montana - Missoula, Donald.potts@umontana.edu

Follow this and additional works at: https://scholarworks.umt.edu/forest_pubs

Part of the Forest Management Commons

Let us know how access to this document benefits you.

\section{Recommended Citation}

Whitaker, Andrew C. and Potts, Donald F., "Analysis of Flow Competence in an Alluvial Gravel Bed Stream, Dupuyer Creek, Montana" (2007). Forest Management Faculty Publications. 13.

https://scholarworks.umt.edu/forest_pubs/13

This Article is brought to you for free and open access by the Forest Management at ScholarWorks at University of Montana. It has been accepted for inclusion in Forest Management Faculty Publications by an authorized administrator of ScholarWorks at University of Montana. For more information, please contact scholarworks@mso.umt.edu. 


\title{
Analysis of flow competence in an alluvial gravel bed stream, Dupuyer Creek, Montana
}

\author{
Andrew C. Whitaker ${ }^{1,2}$ and Donald F. Potts ${ }^{1}$ \\ Received 26 June 2006; revised 28 February 2007; accepted 23 March 2007; published 19 July 2007. \\ [1] Critical shear stress and unit discharge flow competence models were tested against \\ coarse bed load data from Dupuyer Creek, Montana, United States. Maximum particle \\ sizes sampled $\left(D_{\max }\right)$ and $\mathrm{D}_{50}$ to $\mathrm{D}_{90}$ percentiles in the bed load grain size distribution \\ were well correlated with both shear stress and unit discharge. Bed load grain sizes \\ became coarser with increasing flow strength. For the $\mathrm{D}_{\max }$ curve, Shields dimensionless \\ parameter for the surface $\mathrm{D}_{50}$ was estimated at 0.044 , and the exponent for relative particle \\ size $\left(\mathrm{D}_{\mathrm{i}} / \mathrm{D}_{50}\right)$ was -0.59 . In the unit discharge criterion the critical flow to entrain the \\ surface $\mathrm{D}_{50}$ was poorly predicted. Flow competence relationships based on $\mathrm{D}_{\max }$ are prone \\ to the influence of outliers and sample mass variability. The mean of the three largest \\ particles, $D_{\max }(3)$, is more sensitive to changes in flow strength than the $\mathrm{D}_{50}$ to $\mathrm{D}_{90}$ bed \\ load grain sizes, and may represent a good compromise.
}

Citation: Whitaker, A. C., and D. F. Potts (2007), Analysis of flow competence in an alluvial gravel bed stream, Dupuyer Creek, Montana, Water Resour. Res., 43, W07433, doi:10.1029/2006WR005289.

\section{Introduction}

[2] Critical flow condition for the entrainment of bed material is an important consideration for the assessment of stability in gravel bed streams. The concept of flow competence is commonly used to estimate the magnitude of flows necessary to entrain particle sizes present on the stream bed. The broad range of particle sizes present in gravel bed streams makes prediction of bed load initiation extremely complex. Sampling of bed load to validate model predictions has been limited by dangerous conditions during floods, high rates of bed load transport, the need for large orifice samplers, and unmanageable sample sizes [Gomez et al., 1991; Custer, 1992]. Empirical predictive models of bed load transport have therefore been largely developed in laboratory flume experiments, and there is a need to further evaluate their performance in streams with coarse bed materials. Two approaches are described for predicting the competence of streamflow to entrain the channel bed grain sizes, including the critical shear stress approach [Andrews, 1983; Petit, 1994], and the critical unit discharge approach [Bathurst, 1987; Ferguson, 1994]. The validity of these methods, however, in gravel bed streams remains uncertain.

[3] Several studies have shown bed load transport to be size selective over a significant range of flow for gravel bed rivers [e.g., Lenzi et al., 1999; Powell et al., 2001]. Progressively larger particle sizes are entrained with increasing flows [Milhous, 1973; Carling, 1983; Komar, 1987; Ashworth and Ferguson, 1989], and the bed load size distribution becomes coarser [Bunte, 1996; Whitaker, 1997; Powell et al., 2001]. This strong hydraulic control on

\footnotetext{
${ }^{1}$ College of Forestry and Conservation, University of Montana, Missoula, Montana, USA.

${ }^{2}$ Now at Faculty of Agriculture, Niigata University, Niigata, Japan.

Copyright 2007 by the American Geophysical Union. 0043-1397/07/2006WR005289
}

the bed load transport process can be explored through the development and validation of flow competence models. The key difficulty lies in sampling bed load effectively, so that we can link critical flow conditions to the mobility of different sizes or size fractions on the stream bed.

[4] The main objective of this study was to determine whether flow competence relationships could be established in practice for a gravel bed stream and, if so, whether the critical shear stress or the critical unit discharge model is the better predictor. To achieve this objective, we used unique bed load sampling methods which capture only the coarse fractions. A secondary objective was to explore the relative merits of alternative variables in flow competence modeling, such as the mean of the three largest particles, and percentiles of the bed load grain size distribution. We also investigated the sensitivity of flow competence models to estimates of the stream bed surface size distribution (especially the $\mathrm{D}_{50}$ ), and address the issue of variability in sample mass in the bed load data set.

\section{Flow Competence Models}

[5] Intuitively, the concept of flow competence [Gilbert and Murphy, 1914] suggests that stream power limits the maximum particle size that a given flow can transport. Simply put, larger heavier particles require greater stream power before they are entrained than smaller, more lightweight particles, such that relationships can be established between flow and the maximum particle size in motion. We present in Figure 1 a conceptual model of flow competence, which is combined with the two-phase conceptual model of bed load transport proposed by Jackson and Beschta [1982]. Both of the relationships (Figures 1a and 1b) show that a threshold flow or shear stress must be exceeded before bed material is mobilized in phase 1 transport. Tendency toward selective transport or equal mobility can be illustrated through the different shapes of the flow competence curves. In Figure 1a, mobilization of riffle 
(a) Size Selective Transport

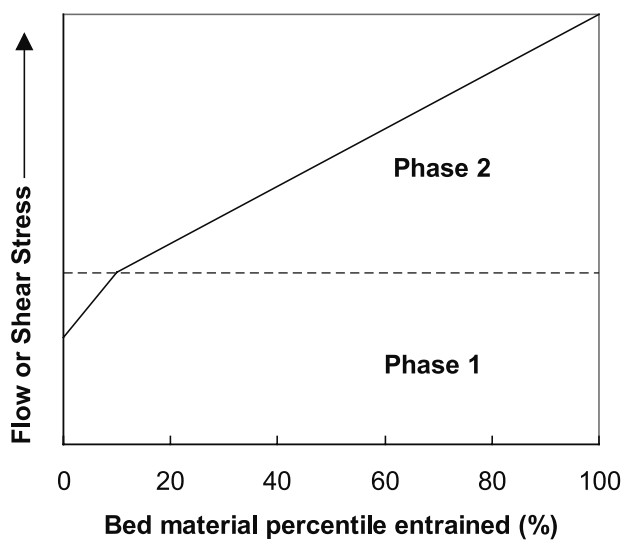

(b) Equal Mobility Transport

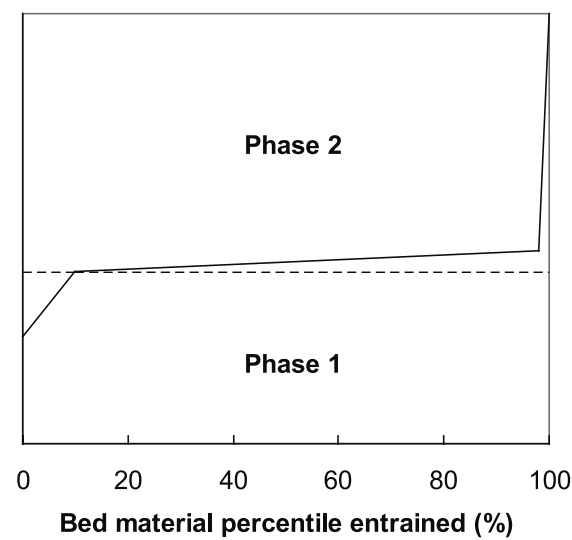

Figure 1. Conceptual illustration of size selective transport (a) versus a combination of selective and equal mobility (b) for bed load transport in heterogeneous sediments. The transition from phase 1 to phase 2 transport occurs when the flow competence curves cross the dashed line.

sediments in phase 2 transport may potentially be accompanied by a change in slope of the flow competence curve. Increasing discharge or shear stress results in progressively larger bed material percentiles being entrained. A more discontinuous relationship for flow competence is proposed in Figure 1b. Particle interactions during entrainment of the riffle sediments cause the majority of the bed material size distribution to be mobilized over a relatively narrow range of flow. In this situation, prediction of stream bed mobility is simplified to the identification of this narrow range of flow or threshold flow. Recent work by Ryan et al. [2005] has shown that the transition from phase 1 to phase 2 bed load transport occurs, on average, at about 80 per cent of the bankfull (1.5-year return interval) discharge, and that movement of the $\mathrm{D}_{16}$ to $\mathrm{D}_{25}$ grain size of the bed surface seems to correspond with the onset of phase 2 transport.

[6] Several potential problems have been identified which may limit our ability to quantify flow competence as presented in Figure 1. Flow competence curves based upon the maximum particle size entrained have been criticized, because characterizing the transported sediments by single or relatively few large particles may be unduly influenced by outliers and sampling errors [Wilcock, 1992]. Additionally, estimates of flow competence based on $\mathrm{D}_{\max }$ may be sensitive to the effect of variability in sample mass, a common feature in gravel bed streams with unsteady transport rates [Wilcock, 1992, 2001]. While we acknowledge these difficulties, it has been shown that maximum particle sizes are an integral part of the overall bed load size distribution, responding clearly to changing flow hydraulics [Komar and Carling, 1991].

[7] The flow components in flow competence analyses can be quantified through either shear stress or unit discharge. In the following section we introduce these two approaches, and describe how they may be applied in practice.

\subsection{Critical Shear Stress}

[8] Flow competence analyses are most commonly based on relationships between flow shear stress exerted at the stream bed and the maximum particle size entrained in bed load transport. The Shields criterion [Shields, 1936] is the most widely used method of predicting thresholds in bed load initiation:

$$
\theta_{\mathrm{ci}}=\tau_{\mathrm{ci}} /\left(\rho_{s}-\rho\right) \mathrm{gD}_{\mathrm{i}}
$$

where $\theta_{\mathrm{ci}}$ and $\tau_{\mathrm{ci}}$ are, respectively, the Shields dimensionless parameter and critical shear stress to entrain a particle of diameter $\mathrm{D}_{\mathrm{i}}(\mathrm{m}), \rho_{\mathrm{s}}$ and $\rho$ are the densities of sediment and water respectively $\left(\mathrm{kg} / \mathrm{m}^{3}\right)$, and $\mathrm{g}$ is the acceleration due to gravity $\left(\mathrm{m} / \mathrm{s}^{2}\right)$. Mean cross-sectional shear stress, $\tau\left(\mathrm{N} / \mathrm{m}^{2}\right)$, is most easily estimated using Du Boys formula:

$$
\tau=\rho \mathrm{gRS}
$$

where $\rho$ is the fluid density $\left(\mathrm{kg} / \mathrm{m}^{3}\right), \mathrm{g}$ the acceleration due to gravity $\left(\mathrm{m} / \mathrm{s}^{2}\right)$, R the hydraulic radius $(\mathrm{m})$, and $\mathrm{S}$ the water surface slope.

[9] Work in gravel bed rivers has shown that the critical shear stress varies as a function of both absolute particle size $\mathrm{D}_{\mathrm{i}}$ and the relative size $\mathrm{D}_{\mathrm{i}} / \mathrm{D}_{50}$ [White and Day, 1982; Parker et al., 1982; Andrews, 1983; Komar, 1987]. The importance of relative particle size is attributed to the hiding/exposure effect. Larger-than-average particles are relatively easier to move because of exposure, and smaller-than-average particles are relatively more difficult to move because of hiding. Andrews [1983] described the effects of hiding and exposure on critical shear stress via the Shields dimensionless parameter:

$$
\theta_{\mathrm{ci}}=\theta\left(\mathrm{D}_{\mathrm{i}} / \mathrm{D}_{50}\right)^{x}
$$

where $\mathrm{D}_{50}$ is the median particle size of the bed material, $\theta$ represents the Shields dimensionless parameter for the surface $\mathrm{D}_{50}$, and the exponent $x$ indicates the rate at which $\theta_{\text {ci }}$ diminishes as $\mathrm{D}_{\mathrm{i}}$ increases. Theoretically, values of $\theta$ and $x$ may be assumed from the literature [e.g., Komar, 1989; Petit, 1994], allowing the critical dimensionless shear stress in (3) to be calculated and used in (1) to determine the critical shear stress for entrainment of a given particle size. Equation (2) can be rearranged to determine the critical hydraulic radius or depth for entrainment, which can then be translated into a critical discharge through a stage discharge 
curve. In practice, however, appropriate values of $\theta$ and $x$ are not known a priori for any given stream site, and there is no algorithm from which to predict appropriate values.

[10] Values for $x$ are negative, but for reasons of simplicity are often reported as positive values. Reported values range from -0.65 to - 1.0 [Andrews, 1983; Ashworth and Ferguson, 1989; Komar, 1989; Parker et al., 1982; Whitaker and Potts, 1996]. Values close to -1.0 suggest that the critical stress to mobilize a particle depends more on particle size relative to the $\mathrm{D}_{50}$ than actual size. In the extreme case of $x=-1.0$, all particle sizes present will move at the same critical stress or discharge demonstrating equal mobility in entrainment [Parker and Klingeman, 1982]. There is consensus that equal mobility is reached at high excess stresses and transport rates, but there is disagreement concerning the range of flows for which entrainment is size-selective [Bunte, 1992a, 1992b; Komar and Shih, 1992].

[11] One reason for the wide range of values obtained for the exponent $x$ is that the critical flow for the entrainment and transport of a given particle size has been defined in two different ways. In one technique, the maximum particle size sampled in transport at different flows is used to define the critical flow condition for mobilization. Similarly, if tracers are placed in the channel, the peak flow in a given flood is defined as critical for the largest particle entrained in that flood, provided larger immobile sizes are present in the channel [Carling, 1983; Komar, 1987; Ashiq and Bathurst, 1999]. An alternative technique examines the relative transport rates of the different grain-size fractions, and the threshold of motion for each size fraction is defined as the flow which produces a small reference transport rate [Parker et al., 1982; Wilcock and Southard, 1988]. This often involves extrapolation of the measured transport discharge rating curve, and hence can be in error if there are discontinuities in this relationship. The technique using maximum sampled particle size may also be in error as bed load sampling is generally undertaken with sample times insufficient to capture the maximum particle size [Wilcock, 1988].

[12] Several practical disadvantages have been documented in applying the critical shear stress approach, especially for steep mountain rivers [Bathurst et al., 1987]. To estimate the hydraulic radius requires accurate information on the channel cross section and flow depth during flood flows. Hydraulic radius is often approximated by mean flow depth when the width to depth ratio is high. However, active scour and deposition or the movement of bed forms during intense bed load transport leads to errors in estimating the channel cross section and mean flow depth [Bathurst et al., 1987].

[13] A further theoretical problem is caused by the fact that total shear stress has two separate components owing to (1) grain resistance over the stream bed surface and (2) bed form resistance related to the shape of the stream bed and banks. In theory, only the shear stress due to grain resistance should be considered in the transport of bed load, but in practice the division of total shear stress into these two components remains problematic. Therefore in most cases, authors have related total shear stress to particle entrainment in deriving flow competence relationships. This approximation is reasonable in relatively wide and shallow channels where bank effects are negligible and grain resistance is the dominant shear stress component [Hey, 1979], but in relatively narrow channels a significant proportion of total shear stress is taken up in overcoming bed form resistance [Carling, 1983].

\subsection{Critical Unit Discharge}

[14] An alternative entrainment criterion follows the Schoklitsch approach [Schoklitsch, 1962, p. 174] which is based on the water discharge per unit flow width rather than on the mean shear stress exerted by the flow. Bathurst et al. [1987] proposed the following equation to predict entrainment of individual size fractions, with adjustment necessary for the hiding and exposure effects:

$$
\mathrm{q}_{\mathrm{c}}=0.15 \mathrm{~g}^{0.5} \mathrm{D}^{1.5} \mathrm{~S}^{-1.12}
$$

where $\mathrm{q}_{\mathrm{c}}$ is the critical unit discharge $\left(\mathrm{m}^{2} / \mathrm{s}\right)$ needed to entrain a particle of diameter $\mathrm{D}(\mathrm{m}), \mathrm{g}$ is acceleration due to gravity $\left(\mathrm{m} / \mathrm{s}^{2}\right)$, and $\mathrm{S}$ is the water surface slope. The above semiempirical equation is based on flume experiments using uniform sediments ranging 3-44 $\mathrm{mm}$ in size, and slopes of $0.25-20 \%$. Bathurst [1987] used this equation to predict entrainment of the reference particle size in heterogeneous stream bed gravels. The reference size is the particle diameter which is unaffected by any hiding or exposure, as in the case of a uniform size bed. The hiding and exposure effects are then modeled in the same form as equation (3):

$$
\mathrm{q}_{\mathrm{ci}}=\mathrm{q}_{\mathrm{cr}}\left(\mathrm{D}_{\mathrm{i}} / \mathrm{D}_{\mathrm{r}}\right)^{b}
$$

where $\mathrm{q}_{\mathrm{ci}}$ is the critical unit discharge for entrainment of a given particle size, $\mathrm{q}_{\mathrm{cr}}$ is the critical unit discharge for the reference size calculated from (4), and $b$ is an exponent. Bathurst [1987] proposed the following relationship to estimate the exponent $b$ in equation (5):

$$
b=1.5\left(\mathrm{D}_{84} / \mathrm{D}_{16}\right)^{-1}
$$

where $\mathrm{D}_{84}$ and $\mathrm{D}_{16}$ refer to the stream bed surface. For uniform sediments $b$ assumes a value of 1.5 , and for widely ranging particle sizes (large ratio $\mathrm{D}_{84} / \mathrm{D}_{16}$ ), $b$ tends toward zero. A smaller value for $b$ will be obtained when a relatively narrow range of discharge entrains all available particle sizes, and indicates a tendency toward greater equal mobility in the initiation of bed load transport.

[15] The unit discharge criterion may be more suitable in steep mountain rivers with boulder beds, where individual particles extend through a significant portion of the flow depth, or even extend above the water surface [Bathurst, 1987; Bathurst et al., 1987]. Under such conditions the assumptions in the shear stress approach are violated, and it is easier to define flow discharge than mean shear stress. In gravel bed streams with slope of about one percent or more, a case may be made for the use of either shear stress or unit discharge entrainment criteria.

[16] Differences in the arrangement and mix of particle sizes also play a significant role in determining the critical stress or flow required to initiate movement of particles on the stream bed [Reid et al., 1985; Powell and Ashworth, 1995], so that for any given particle size, the critical flow can vary several fold, even after allowance for the hiding/ exposure effect. This unpredictable variation in the critical 
flow condition required to mobilize stream bed sediments hinders the application of either the shear stress or unit discharge criteria.

\section{Study Area}

[17] Dupuyer Creek originates east of the Continental Divide in the Sawtooth Range of Montana's Rocky Mountain Front, a tributary of the Missouri River (Figure 2a). Stream gauging and bed load sampling were carried out approximately $8 \mathrm{~km}$ from the mountain front, giving a catchment area of $83 \mathrm{~km}^{2}$ [Whitaker and Potts, 2007]. The seasonal flow regime is dominated by May and June floods caused by frontal rainfall and snowmelt, and throughout the rest of the year low flow conditions are common. Above the sampling site the channel is meandering single thread in an alluvial valley, with alternate, transverse, and midchannel bars, and sequences of riffles and pools. Bankfull width is $9 \mathrm{~m}$, mean slope is 1.0 percent, and channel bed materials are predominantly gravels and cobbles with a surface $\mathrm{D}_{50}$ of $56 \mathrm{~mm}$ at the riffle sampling point. Wolman pebble counts [Wolman, 1954] in three different areas of the riffle where bed load was sampled showed that the $\mathrm{D}_{50}$ ranged from $45-63 \mathrm{~mm}$, and the $\mathrm{D}_{84}$ ranged from $100-112 \mathrm{~mm}$. At the reach scale ( $76 \%$ riffle, $24 \%$ pool), a stratified pebble count encompassing five riffles and five pools upstream from the sampling bridge showed the $\mathrm{D}_{50}$ to be $42 \mathrm{~mm}$. High sediment supply and channel bed mobility is evidenced by the absence of an obvious coarse armor layer, loose arrangement of particles, smooth and rounded particle shapes, and freshly deposited bars containing the full range of available particle sizes. Widespread bank erosion and channel migration also indicate that bed load transport is unlimited by the supply of sediment.

\section{Methods}

\subsection{Sampling of Maximum Bed Load Sizes}

[18] Classic flow competence criteria relate streamflow parameters to a maximum particle size that can be entrained. In validating such flow competence criteria it is essential that the largest particles in motion on the stream bed can be efficiently sampled, and related to flow conditions at the time of sampling. Helley-Smith type bed load samplers [Helley and Smith, 1971] have been designed to capture the finer bed load fractions, and they are incapable of capturing the maximum particle sizes in motion when these sizes approach or exceed the sampler nozzle size in coarse gravel channels [Custer, 1992; Sterling and Church, 2002; Vericat et al., 2006]. Pit traps may be effective in capturing the maximum particle sizes [e.g., Reid et al., 1985] although integrated samples are generally obtained over a complete flood event making it difficult to link critical flows with specific particle sizes. This investigation used a large-frame $(0.45 \mathrm{~m}$ by $1 \mathrm{~m})$ bed load sampler with a large mesh size (32 $\mathrm{mm}$ ) to capture coarse particles in motion over discrete periods of the flood hydrograph (Figure 2b). This type of sampler was first used by Bunte [1992a, 1996], and aspects of the sampler design and operation are discussed by Whitaker and Potts [2007]. The fine bed load fraction, and total rates of bed load flux cannot be measured with a large mesh size, but this compromise was necessary when the primary purpose of sampling was to investigate coarse bed load characteristics. Trap efficiency was assumed to be 100 percent for particles $38 \mathrm{~mm}$ or larger in the $b$ axis dimension and the data were truncated at this size (equivalent to $\mathrm{D}_{30}$ on stream bed surface at midriffle sampling point). The truncation at $38 \mathrm{~mm}$ (mesh size plus $6 \mathrm{~mm}$ ) was dictated in part by the available sieve sizes. All bed load samples were hand sieved in the field with Gilson screens of $76,64,51$, and $38 \mathrm{~mm}$ sizes, and the $b$ axis of particles larger than $76 \mathrm{~mm}$ measured by ruler to the nearest $\mathrm{mm}$.

[19] A total of 120 individual bed load samples was obtained during two spring runoff events at Dupuyer Creek (Table 1). Sample duration ranged from 1 minute during peak bed load activity, to 60 minutes during marginal bed load activity, with a mean sample size of $21 \mathrm{~kg}$ and a maximum of $116 \mathrm{~kg}$ (respectively $40 \mathrm{~kg}$ and $242 \mathrm{~kg}$ before truncation at $38 \mathrm{~mm}$ ). As found in previous studies, bed load transport was unsteady with sediment moving in pulses or waves, even during steady flow conditions [e.g., Leopold and Emmett, 1976; Ergenzinger and Custer, 1983; Reid et al., 1985; Iseya and Ikeda, 1987; Kuhnle and Southard, 1988; Dinehart, 1989; Gomez et al., 1989]. A single sample may not contain the largest particles in motion under the prevailing flow conditions. Therefore the data were analyzed by grouping sequential individual samples into composite samples (hereafter referred to as sample groups) over periods of $1-3$ hours during which discharge remained relatively steady $( \pm 5 \%)$, giving total sample times of between 8 and 140 minutes (Table 2). To test the flow competence criteria, the mean flow condition during each sample group period was plotted against the maximum particle size (and the mean of the three largest particle sizes). By grouping individual samples into sample groups, we effectively increased the sample duration to improve our chances of capturing the largest particles in motion at any given level of shear stress or discharge. The grouping of samples is also discussed in Whitaker and Potts [2007] which describes trends in the fractional transport of bed load at Dupuyer Creek.

\subsection{Estimation of Hydraulic Parameters}

[20] Flow velocities were measured with a Price AA current meter. When flows could be waded, the current meter was attached to a wading rod with readings taken every $30 \mathrm{~cm}$ across the channel. At high flows, the current meter was attached above a $14 \mathrm{~kg}$ sounding weight and operated using a cable and hand reel from the sampling bridge (Figure 2b). Flow depths were less than $0.7 \mathrm{~m}$, so that velocities could be measured at 0.6 times depth from the surface to give an estimate of average velocity at each vertical [Rantz et al., 1982]. To confirm the stage-rating curve, discharge was measured on each occasion that bed load samples were taken.

[21] At the sampling point, the channel cross section is relatively wide and shallow (trapezoidal) so that when using the Du Boys equation (2) to estimate mean cross-sectional shear stress, the hydraulic radius can be approximated by mean flow depth $(\mathrm{R}=0.97 \mathrm{~d}$ when bed load activity marginal, and $0.95 \mathrm{~d}$ for maximum sampled flow). Mean flow depth should be calculated only across that portion of the channel bed which is active in transporting bed load [Andrews, 1983]. At Dupuyer Creek, bed load was detected 
(a)

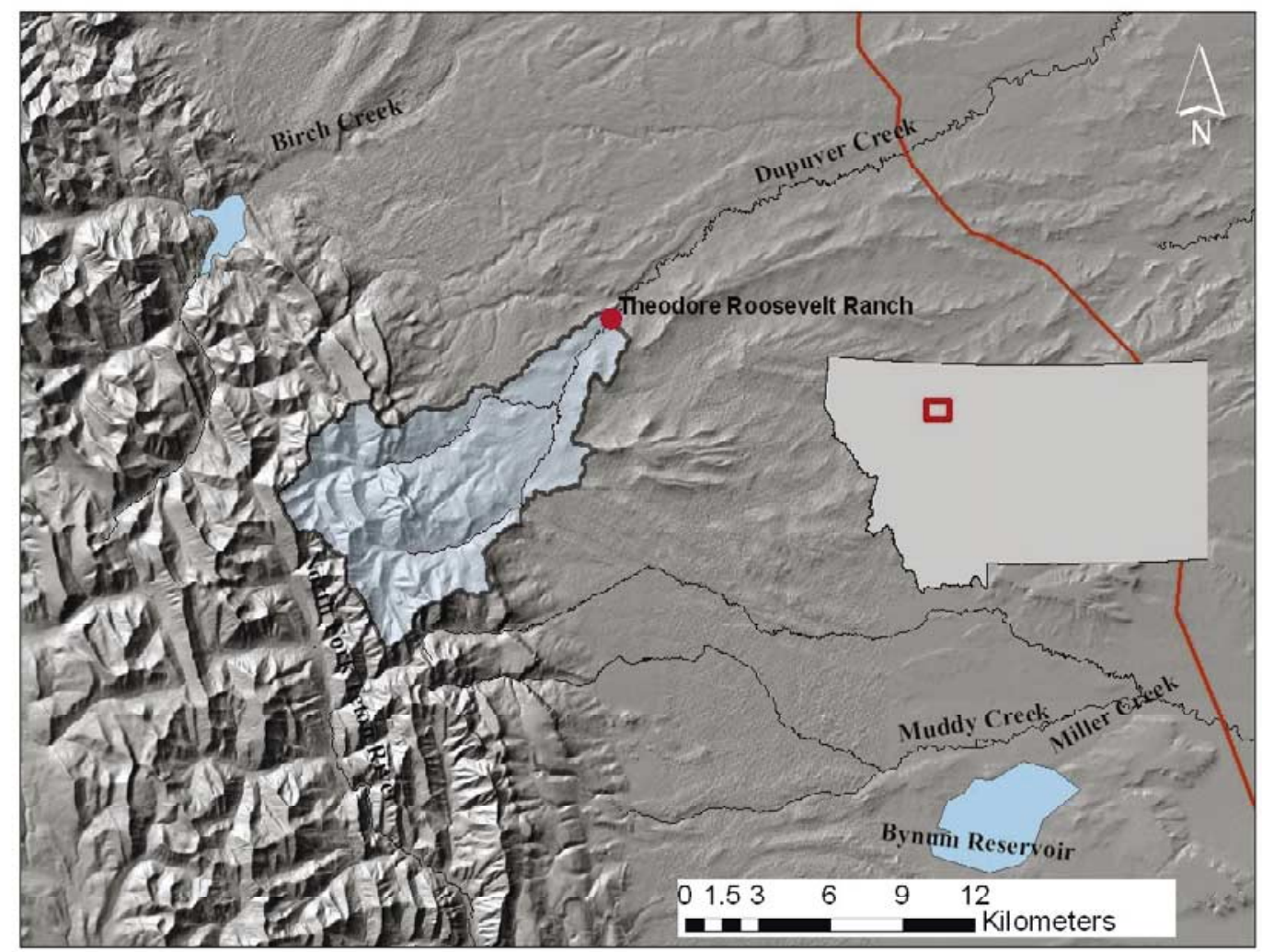

(b)

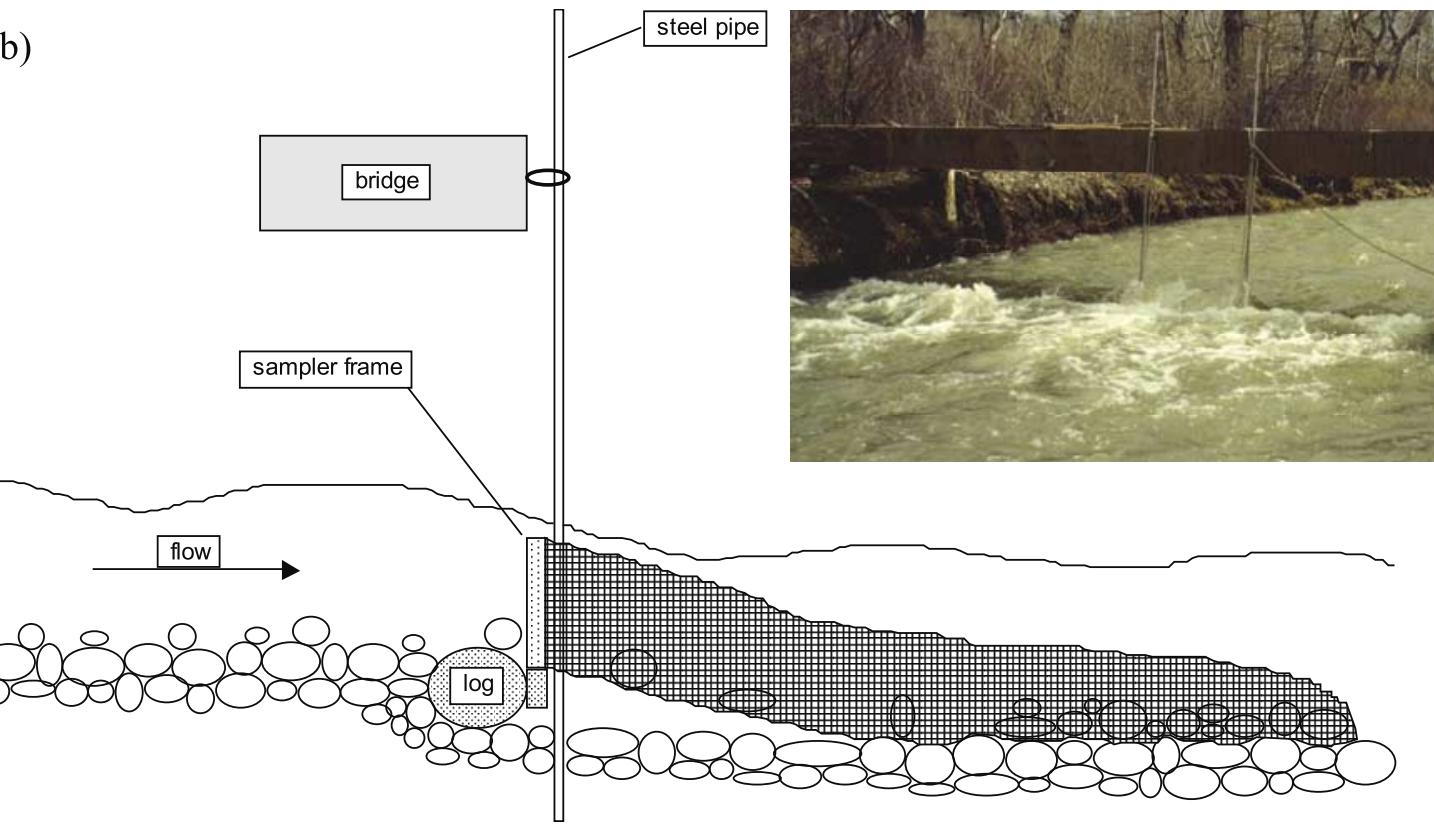

Figure 2. (a) Location of Dupuyer Creek on the Rocky Mountain Front of Montana. Watershed boundary is defined for the gauging station and point of bed load sampling, located at the Theodore Roosevelt Ranch. (b) Schematic illustration of large-frame bed load sampler with inset photograph showing deployment during low flow conditions.

across almost the entire width, and only the outer meter against each bank was considered inactive and excluded from the mean depth calculations (for a discussion on lateral variation in shear stress, see Ferguson [2003]).
[22] Water surface slope is an important hydraulic variable, which is rarely measured in space and time at field sites during sediment transport [Prestegaard, 1983; Meirovich et al., 1998]. We tried the "slope tube" technique [Custer, 
Table 1. Three Largest Particle Sizes Together With Sample Mass (>38 mm Fraction) and Flow Conditions for Each of the 120 Individual Bed Load Samples Obtained in the May and June Floods, $1995^{\text {a }}$

\begin{tabular}{|c|c|c|c|c|c|c|c|}
\hline \multirow[b]{2}{*}{ Sample ID } & \multirow{2}{*}{$\begin{array}{c}\text { Mass, } \\
\text { kg }\end{array}$} & \multicolumn{4}{|c|}{ Largest Bed Load $b$ Axes, mm } & \multirow{2}{*}{$\begin{array}{c}\tau, \\
\mathrm{N} / \mathrm{m}^{2}\end{array}$} & \multirow{2}{*}{$\underset{\mathrm{m}^{2} / \mathrm{s}}{\mathrm{q}}$} \\
\hline & & $\mathrm{D}_{\max }$ & Second & Third & Mean & & \\
\hline 1 & 10.6 & 120 & & & & 57.2 & 1.02 \\
\hline 2 & 4.9 & 100 & & & & 56.9 & 1.01 \\
\hline 3 & 5.7 & 90 & & & & 56.4 & 0.99 \\
\hline 4 & 28.6 & 135 & & & & 56.1 & 0.98 \\
\hline 5 & 25.8 & 104 & & & & 55.9 & 0.97 \\
\hline 6 & 34.7 & 134 & & & & 55.6 & 0.96 \\
\hline 7 & 17.0 & 90 & & & & 55.3 & 0.95 \\
\hline 8 & 115.7 & 155 & 130 & & 143 & 55.3 & 0.91 \\
\hline 9 & 49.9 & 120 & 116 & 95 & 110 & 55.3 & 0.91 \\
\hline 10 & 62.0 & 105 & 103 & 98 & 102 & 55.3 & 0.91 \\
\hline 11 & 2.0 & 70 & 60 & & 65 & 55.0 & 0.90 \\
\hline 12 & 100.9 & 125 & 110 & 110 & 115 & 55.0 & 0.90 \\
\hline 13 & 12.2 & 110 & 100 & 74 & 95 & 55.0 & 0.90 \\
\hline 14 & 8.2 & 75 & 74 & 64 & 71 & 55.0 & 0.90 \\
\hline 15 & 5.2 & 74 & 60 & 54 & 63 & 55.0 & 0.90 \\
\hline 16 & 18.4 & 131 & 80 & 67 & 93 & 55.0 & 0.90 \\
\hline 17 & 12.3 & 89 & 80 & 75 & 81 & 53.7 & 0.85 \\
\hline 18 & 18.1 & 78 & 68 & 68 & 71 & 53.7 & 0.85 \\
\hline 19 & 8.8 & 70 & 65 & 65 & 67 & 54.5 & 0.88 \\
\hline 20 & 24.6 & 117 & 98 & 85 & 100 & 54.0 & 0.86 \\
\hline 21 & 35.9 & 175 & 100 & 95 & 123 & 54.0 & 0.86 \\
\hline 22 & 21.8 & 76 & 72 & 69 & 72 & 53.4 & 0.84 \\
\hline 23 & 49.2 & 124 & 100 & 100 & 108 & 53.4 & 0.84 \\
\hline 24 & 12.7 & 80 & 73 & 66 & 73 & 54.8 & 0.89 \\
\hline 25 & 22.3 & 106 & 95 & 80 & 94 & 54.8 & 0.89 \\
\hline 26 & 35.3 & 105 & 93 & 90 & 96 & 54.8 & 0.89 \\
\hline 27 & 22.6 & 98 & 87 & 87 & 91 & 55.0 & 0.90 \\
\hline 28 & 6.5 & 76 & 76 & 71 & 74 & 52.3 & 0.81 \\
\hline 29 & 6.3 & 75 & 75 & 58 & 69 & 52.3 & 0.81 \\
\hline 30 & 49.2 & 109 & 93 & 86 & 96 & 52.3 & 0.81 \\
\hline 31 & 26.9 & 85 & 83 & 80 & 83 & 52.1 & 0.80 \\
\hline 32 & 4.9 & 68 & 64 & 62 & 65 & 52.3 & 0.81 \\
\hline 33 & 9.1 & 88 & 74 & 70 & 77 & 52.3 & 0.81 \\
\hline 34 & 20.0 & 85 & 80 & 70 & 78 & 51.8 & 0.79 \\
\hline 35 & 20.1 & 123 & 87 & 85 & 98 & 51.0 & 0.76 \\
\hline 36 & 10.4 & 86 & 84 & 75 & 82 & 51.5 & 0.78 \\
\hline 37 & 2.8 & 64 & 62 & 58 & 61 & 51.0 & 0.76 \\
\hline 38 & 21.0 & 89 & 88 & 79 & 85 & 51.5 & 0.78 \\
\hline 39 & 6.9 & 70 & 70 & 61 & 67 & 51.8 & 0.79 \\
\hline 40 & 2.6 & 59 & 58 & 55 & 57 & 47.5 & 0.65 \\
\hline 41 & 1.0 & 65 & 52 & 50 & 56 & 47.2 & 0.64 \\
\hline 42 & 23.9 & 100 & 78 & 75 & 84 & 48.0 & 0.67 \\
\hline 43 & 36.8 & 90 & 82 & 81 & 84 & 47.5 & 0.65 \\
\hline 44 & 0.5 & 54 & 50 & 49 & 51 & 47.2 & 0.64 \\
\hline 45 & 12.6 & 78 & 72 & 70 & 73 & 46.9 & 0.63 \\
\hline 46 & 0.9 & 58 & 57 & 52 & 56 & 46.4 & 0.62 \\
\hline 47 & 7.5 & 70 & 65 & 61 & 65 & 46.1 & 0.61 \\
\hline 48 & 15.6 & 75 & 74 & 65 & 71 & 46.4 & 0.62 \\
\hline 49 & 77.7 & 94 & 88 & 74 & 85 & 45.8 & 0.60 \\
\hline 50 & 4.5 & 88 & 80 & 76 & 81 & 45.0 & 0.58 \\
\hline 51 & 7.3 & 75 & 70 & 66 & 70 & 45.3 & 0.59 \\
\hline 52 & 6.5 & 82 & 80 & 64 & 75 & 45.3 & 0.59 \\
\hline 53 & 5.7 & 85 & 70 & 58 & 71 & 45.0 & 0.58 \\
\hline 54 & 4.0 & 82 & & & & 45.3 & 0.59 \\
\hline 55 & 3.9 & 103 & 80 & 75 & 86 & 56.7 & 0.89 \\
\hline 56 & 29.4 & 103 & 99 & 81 & 94 & 57.2 & 0.91 \\
\hline 57 & 7.6 & 100 & 75 & 70 & 82 & 57.5 & 0.92 \\
\hline 58 & 18.5 & 120 & 110 & 106 & 112 & 57.5 & 0.92 \\
\hline 59 & 1.8 & 71 & 60 & 60 & 64 & 57.2 & 0.91 \\
\hline 60 & 4.7 & 74 & 73 & 64 & 70 & 57.7 & 0.93 \\
\hline 61 & 3.6 & 108 & 72 & 63 & 81 & 57.5 & 0.92 \\
\hline 62 & 31.8 & 94 & 88 & 77 & 86 & 58.0 & 0.94 \\
\hline 63 & 23.8 & 105 & 85 & 82 & 91 & 57.7 & 0.93 \\
\hline 64 & 7.8 & 115 & 88 & 76 & 93 & 57.7 & 0.93 \\
\hline 65 & 16.4 & 96 & 88 & 85 & 90 & 58.0 & 0.94 \\
\hline 66 & 24.0 & 87 & 79 & 75 & 80 & 58.0 & 0.94 \\
\hline 67 & 30.5 & 103 & 95 & 83 & 94 & 58.3 & 0.95 \\
\hline
\end{tabular}

Table 1. (continued)

\begin{tabular}{|c|c|c|c|c|c|c|c|}
\hline \multirow[b]{2}{*}{ Sample ID } & \multirow{2}{*}{$\begin{array}{c}\text { Mass, } \\
\mathrm{kg}\end{array}$} & \multicolumn{4}{|c|}{ Largest Bed Load $b$ Axes, mm } & \multirow{2}{*}{$\begin{array}{c}\tau, \\
\mathrm{N} / \mathrm{m}^{2}\end{array}$} & \multirow{2}{*}{$\underset{\mathrm{m}^{2} / \mathrm{s}}{\mathrm{q}}$} \\
\hline & & $\mathrm{D}_{\max }$ & Second & Third & Mean & & \\
\hline 68 & 5.5 & 93 & & & & 58.0 & 0.94 \\
\hline 69 & 19.0 & 91 & 76 & 72 & 80 & 59.1 & 0.98 \\
\hline 70 & 6.9 & 89 & 87 & 86 & 87 & 63.2 & 1.13 \\
\hline 71 & 5.9 & 105 & 89 & 77 & 90 & 62.9 & 1.12 \\
\hline 72 & 17.4 & 113 & 87 & 82 & 94 & 63.7 & 1.15 \\
\hline 73 & 16.9 & 100 & 93 & 75 & 89 & 64.0 & 1.17 \\
\hline 74 & 1.5 & 64 & & & & 64.2 & 1.18 \\
\hline 75 & 12.6 & 122 & 103 & 67 & 97 & 64.0 & 1.17 \\
\hline 76 & 20.5 & 120 & 104 & 87 & 104 & 64.5 & 1.19 \\
\hline 77 & 48.2 & 124 & 120 & 105 & 116 & 65.1 & 1.21 \\
\hline 78 & 10.0 & 102 & 96 & 89 & 96 & 66.1 & 1.25 \\
\hline 79 & 47.3 & 146 & 113 & 105 & 121 & 66.4 & 1.27 \\
\hline 80 & 24.2 & 96 & 91 & 89 & 92 & 66.7 & 1.28 \\
\hline 81 & 84.7 & 144 & 124 & 120 & 129 & 67.2 & 1.30 \\
\hline 82 & 9.1 & 110 & 85 & 83 & 93 & & 1.69 \\
\hline 83 & 24.0 & 98 & 95 & 81 & 91 & 63.6 & 1.14 \\
\hline 84 & 5.6 & 95 & 90 & 75 & 87 & 62.1 & 1.09 \\
\hline 85 & 21.8 & 114 & 88 & 77 & 93 & 64.4 & 1.17 \\
\hline 86 & 25.9 & 107 & 100 & 92 & 100 & 62.1 & 1.09 \\
\hline 87 & 15.3 & 94 & 94 & 90 & 93 & 62.4 & 1.10 \\
\hline 88 & 30.1 & 96 & 94 & 91 & 94 & 61.8 & 1.08 \\
\hline 89 & 50.9 & 127 & 112 & 98 & 112 & 63.6 & 1.14 \\
\hline 90 & 21.6 & 105 & 86 & 86 & 92 & 63.0 & 1.12 \\
\hline 91 & 2.8 & 84 & 59 & 59 & 67 & 61.8 & 1.08 \\
\hline 92 & 5.4 & 67 & 65 & 61 & 64 & 63.0 & 1.12 \\
\hline 93 & 32.5 & 95 & 85 & 81 & 87 & 62.1 & 1.09 \\
\hline 94 & 13.3 & 144 & 107 & 84 & 112 & 63.6 & 1.14 \\
\hline 95 & 46.3 & 110 & 92 & 92 & 98 & 60.6 & 1.04 \\
\hline 96 & 21.5 & 85 & 71 & 68 & 75 & 53.2 & 0.84 \\
\hline 97 & 28.8 & 84 & 74 & 74 & 77 & 53.8 & 0.86 \\
\hline 98 & 38.7 & 121 & 98 & 84 & 101 & 51.1 & 0.78 \\
\hline 99 & 37.0 & 98 & 89 & 88 & 92 & 52.6 & 0.82 \\
\hline 100 & 10.4 & 97 & 75 & 68 & 80 & 51.7 & 0.80 \\
\hline 101 & 1.8 & 62 & 56 & 46 & 55 & 53.2 & 0.84 \\
\hline 102 & 5.5 & 109 & 65 & 63 & 79 & 51.7 & 0.80 \\
\hline 103 & 9.4 & 80 & 78 & 69 & 76 & 51.7 & 0.80 \\
\hline 104 & 1.9 & 66 & 59 & 58 & 61 & 51.7 & 0.80 \\
\hline 105 & 46.8 & 92 & 87 & 83 & 87 & 52.3 & 0.81 \\
\hline 106 & 14.7 & 76 & 75 & 74 & 75 & 47.3 & 0.69 \\
\hline 107 & 81.4 & 95 & 89 & 87 & 90 & 47.3 & 0.69 \\
\hline 108 & 10.4 & 94 & 69 & 64 & 76 & 47.9 & 0.70 \\
\hline 109 & 10.2 & 84 & 81 & 76 & 80 & 48.8 & 0.73 \\
\hline 110 & 4.7 & 75 & 63 & 53 & 64 & 49.4 & 0.75 \\
\hline 111 & 10.3 & 80 & 65 & 65 & 70 & 49.1 & 0.74 \\
\hline 112 & 5.7 & 65 & 56 & 56 & 59 & 48.5 & 0.72 \\
\hline 113 & 32.2 & 95 & 83 & 80 & 86 & 49.1 & 0.74 \\
\hline 114 & 57.6 & 98 & 90 & 87 & 92 & 48.8 & 0.73 \\
\hline 115 & 4.5 & 89 & 85 & 69 & 81 & 49.7 & 0.75 \\
\hline 116 & 19.9 & 87 & 67 & 67 & 74 & 48.8 & 0.73 \\
\hline 117 & 25.5 & 97 & 95 & 81 & 91 & 48.8 & 0.73 \\
\hline 118 & 17.0 & 94 & 87 & 86 & 89 & 49.7 & 0.75 \\
\hline 119 & 11.2 & 100 & 89 & 73 & 87 & 49.1 & 0.74 \\
\hline 120 & 20.5 & 81 & 73 & 70 & 75 & 49.4 & 0.75 \\
\hline
\end{tabular}

${ }^{\mathrm{a}}$ Shear stress, $\tau$, and unit discharge, $\mathrm{q}$, are mean cross sectional values. Samples 1-54: 6-10 May 1995. Samples 55-120: 6-11 June 1995.

1992; Bunte, 1996] to measure slope during floods, but found that accurate readings were made impossible owing to continual fluctuations in the water level of the raised tube. Therefore surveyed reach average stream bed slope (1.0 percent) was used in all flow competence analyses.

\subsection{Stream Bed Size Distribution}

[23] The particle size distribution of the stream bed surface was sampled by Wolman pebble counts [Wolman, 1954], using a grid spacing of $0.5 \mathrm{~m}$ across the bankfull 
Table 2. Characteristics of the Bed Load Sample Groups Including Particle Sizes and Hydraulic Conditions Used in the Flow Competence Analysis ${ }^{\mathrm{a}}$

\begin{tabular}{|c|c|c|c|c|c|c|c|c|c|c|}
\hline \multirow[b]{2}{*}{ Group } & \multicolumn{3}{|c|}{ Samples } & \multicolumn{4}{|c|}{$\begin{array}{l}\text { Bed Load Particle Sizes, }>38 \mathrm{~mm} \\
\text { fraction, } \mathrm{mm}\end{array}$} & \multirow[b]{2}{*}{$\tau, \mathrm{N} / \mathrm{m}^{2}$} & \multirow[b]{2}{*}{$\mathrm{q}, \mathrm{m}^{2} / \mathrm{s}$} & \multirow[b]{2}{*}{$\mathrm{Q} / \mathrm{Q}_{\mathrm{bf}}$} \\
\hline & ID & Time, $\min$ & Mass, kg & $\mathrm{D}_{\max }$ & $\mathrm{D}_{\max }(3)$ & $\mathrm{D}_{90}$ & $\mathrm{D}_{50}$ & & & \\
\hline 1 & $1-7$ & 13 & 127 & 135 & & & & 56.2 & 0.98 & 1.15 \\
\hline 2 & $8-10$ & 8 & 228 & 155 & 135 & 89 & 59 & 55.3 & 0.91 & 1.11 \\
\hline 3 & $11-19$ & 36 & 186 & 131 & 122 & 89 & 50 & 54.7 & 0.89 & 1.08 \\
\hline 4 & $20-26$ & 14 & 202 & $175^{\mathrm{b}}$ & 122 & 87 & 50 & 54.1 & 0.87 & 1.06 \\
\hline 5 & $28-39$ & 26 & 184 & 123 & 108 & 72 & 49 & 51.7 & 0.79 & 0.96 \\
\hline 6 & $40-45$ & 28 & 77 & 100 & 91 & 64 & 48 & 47.3 & 0.65 & 0.79 \\
\hline 7 & $46-49$ & 56 & 102 & 94 & 86 & 62 & 47 & 46.1 & 0.61 & 0.75 \\
\hline 8 & $50-54$ & 140 & 28 & 88 & 85 & & & 45.2 & 0.58 & 0.71 \\
\hline 9 & $55-69$ & 30 & 229 & 120 & 115 & 80 & 53 & 57.7 & 0.93 & 1.22 \\
\hline 10 & $70-81$ & 24 & 296 & 146 & 138 & 113 & 60 & 64.9 & 1.20 & 1.58 \\
\hline 11 & $83-95$ & 15 & 296 & 144 & 128 & 93 & 55 & 62.5 & 1.11 & 1.56 \\
\hline 12 & $96-105$ & 40 & 202 & 121 & 109 & 74 & 50 & 52.3 & 0.81 & 1.12 \\
\hline 13 & $106-114$ & 48 & 227 & 98 & 96 & 71 & 50 & 48.5 & 0.72 & 0.97 \\
\hline 14 & $115-120$ & 24 & 99 & 100 & 97 & 79 & 52 & 49.3 & 0.74 & 1.00 \\
\hline
\end{tabular}

${ }^{\mathrm{a} B a n k f u l l ~ d i s c h a r g e,} \mathrm{Q}_{\mathrm{bf}}$, estimated as $6.5 \mathrm{~m}^{3} / \mathrm{s}$ with a bankfull width of approximately $9 \mathrm{~m}$.

${ }^{\mathrm{b}}$ Removing this outlier (as in $\mathrm{D}_{\max }$ (or)), the value becomes $124 \mathrm{~mm}$.

channel width, and measuring particle $b$ axis by ruler to the nearest $\mathrm{mm}$. Two types of pebble count were performed over the study reach. The first type took samples of 100 pebbles each from three zones (upper, middle, and lower riffle) to estimate the size distribution immediately upstream from where bed load was sampled. The second type of pebble count was undertaken to obtain an estimate of the size distribution at the reach scale, sampling over several hundred meters of channel, encompassing five riffles and five pools upstream from the sampling bridge. One thousand particles were measured in this larger-scale stratified pebble count. The pool/riffle ratio was determined through pacing, and the proportions were used to dictate the number of pebbles measured in pools versus riffles.

\section{Results}

\subsection{Critical Shear Stress}

[24] First, we show the results of applying the critical shear stress method through equations (1) to (3) in the evaluation of flow competence. We present the results for flow competence as defined by maximum particle sizes, followed by an examination of the sensitivity of flow competence relationships to estimated particle sizes, and finally we examine flow competence in terms of the changing caliber of sampled bed load percentiles with varying flow stress.

\subsubsection{Maximum Particle Size Relationships}

[25] When mean cross-sectional shear stress is plotted against the maximum particle size for each individual bed load sample, a wide range of scatter is seen (Figure 3 ). The pulsing nature of the bed load means that any single sample may not contain the largest particle size capable of being transported under the prevailing flow conditions. The largest particles move in pulses with intervals that often exceed the manageable sample duration. Unsteady transport of coarse bed load, together with the practical constraints on sample sizes which could be removed from the stream bed, necessitated the aggregation of series of smaller individual samples into sample groups (Table 2).

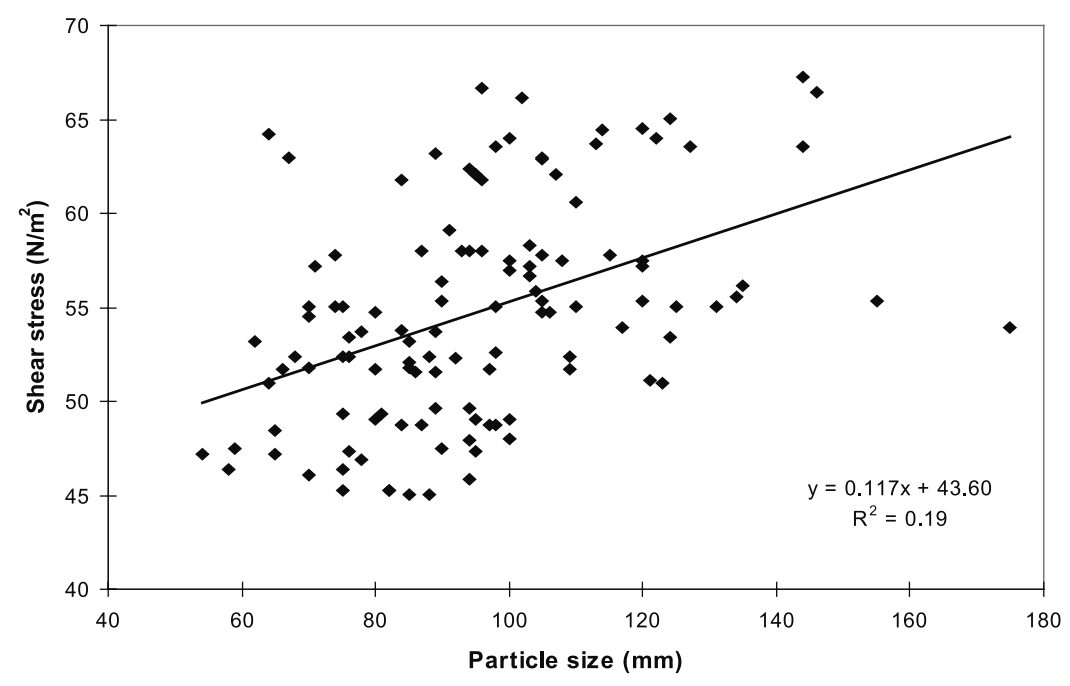

Figure 3. Relationship between cross-sectional shear stress and the maximum particle size, $D_{\max }$, for the 120 individual bed load samples taken during the two floods of 6-10 May and 6-11 June 1995. 


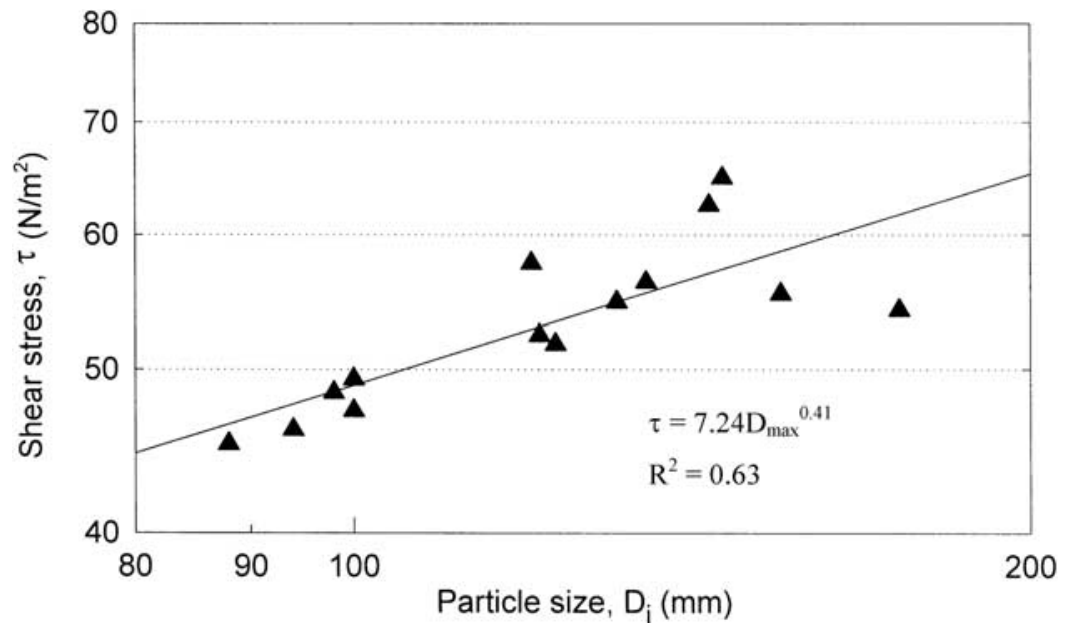

Figure 4. Averaged cross-sectional shear stress against the absolute maximum particle size $\left(\mathrm{D}_{\max }\right.$, not averaged) for each bed load sample group. Scales are log-log, and power regression plots as a straight line.

[26] The relationship between the absolute maximum particle size $\left(\mathrm{D}_{\max }\right.$, not averaged) in each sample group and the mean shear stress shows considerably less scatter (Figure 4). A power regression line was fitted, although for higher shear stresses and particle sizes there is a noticeable increase in the scatter of the data $\left(\mathrm{R}^{2}=0.63\right)$.

[27] Plotting critical dimensionless shear stress against relative particle size computed for the Dupuyer Creek data (Figure 5) shows an inverse relationship similar to the one shown by Andrews [1983]. A power regression relationship can be fitted $\left(\mathrm{R}^{2}=0.77\right)$ to determine the slope $x$ and the coefficient $\theta$ in equation (3). However, the slope of -0.59 is a little less steep compared to values found in other studies (Table 3, by definition, $x=$ Figure 5 slope $=$ Figure 4 slope $-1)$. Reported values of $x$ range between -0.68 and -0.98 , while the -0.59 for Dupuyer Creek indicates slightly greater size selectivity in bed load entrainment. At Dupuyer Creek the smallest $D_{\max }$ for the sample groups was a relatively large $88 \mathrm{~mm}$, corresponding to a relative particle size of 1.57. We found that even when coarse bed load flux was marginal on the falling limb of the May flood $(0.001 \mathrm{~kg} / \mathrm{s} / \mathrm{m}$ for $>38 \mathrm{~mm}$ fraction), we were still capturing relatively coarse bed load particles approximately 1.5 times larger than the surface $\mathrm{D}_{50}$ size. Therefore to estimate $\theta$, representing the critical dimensionless shear stress coefficient for the surface $\mathrm{D}_{50}$, required extrapolation of the power equation beyond the sampled data range. The obtained value of 0.044 for $\theta(95 \%$ confidence limits: $0.0402,0.0474)$ is similar to lower-end values found by researchers on other streams (Table 3).

\subsubsection{Sensitivity to Estimated Particle Sizes}

[28] Flow competence analysis is dependent on accurate estimates of the stream bed size distribution and the maximum particle sizes entrained across a range of flow conditions. The modeling of particle hiding and exposure relies upon a good estimate of the stream bed surface $\mathrm{D}_{50}$, while the maximum particle sizes captured in bed load sampling $\left(\mathrm{D}_{\max }\right)$ are critical in defining the flow competence relationship. In this section, we examine the sensitiv-

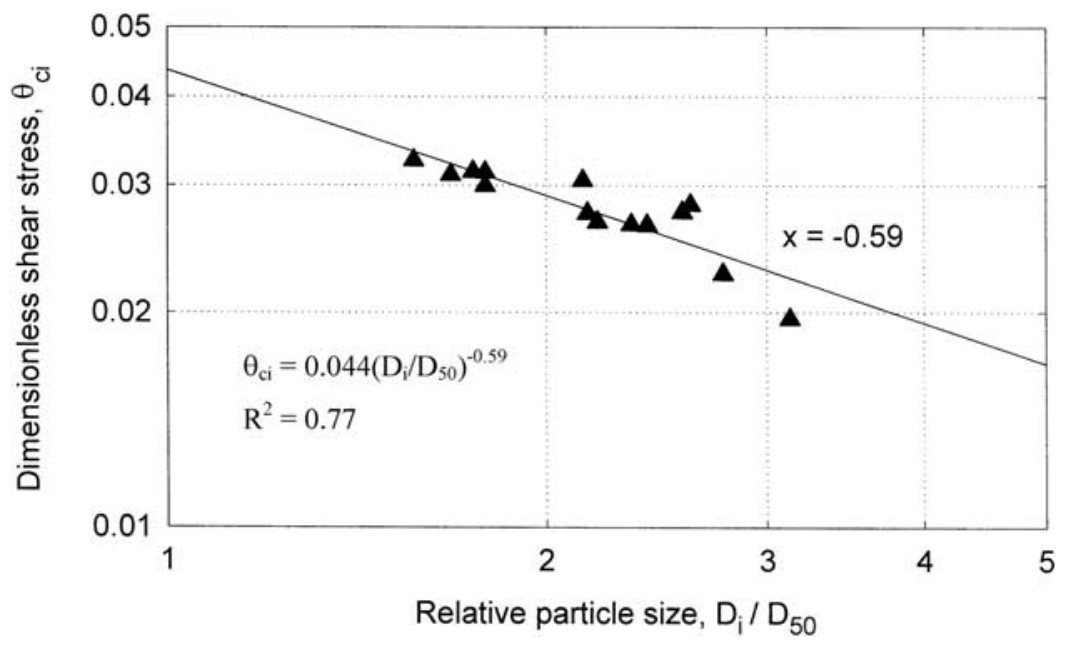

Figure 5. Critical dimensionless shear stress against relative particle size. The slope of the power regression line gives a value of -0.59 for $x$ in equation (3). The critical dimensionless shear stress for $\mathrm{D}_{50}$ ( $\theta$ in equation (3)) is estimated to be 0.044 (95\% confidence limits: 0.040 and 0.047$)$. 
Table 3. Values of $\theta$ and $x$ in $\theta_{\mathrm{ci}}=\theta\left(\mathrm{D}_{\mathrm{i}} / \mathrm{D}_{50}\right)^{x}$ From Petit [1994]

\begin{tabular}{cclll}
\hline$\theta$ & $x$ & $\mathrm{D}_{50}, \mathrm{~mm}$ & \multicolumn{1}{c}{$\mathrm{D}_{\mathrm{i}} / \mathrm{D}_{50}$} & \multicolumn{1}{c}{ Reference } \\
\hline 0.088 & -0.98 & $1.3-25$ & $0.045-4.2$ & Parker et al. [1982] \\
0.083 & -0.87 & $54-74$ & $0.3-4.2$ & Andrews [1983] \\
0.045 & -0.68 & 20 & $0.4-5.9$ & Milhous [1973] in Komar [1987] \\
0.045 & -0.68 & 20 & $0.5-10$ & Carling [1983] \\
0.045 & -0.71 & 7.5 & $0.67-5.33$ & Hammond et al. [1984] \\
0.089 & -0.74 & $23-98$ & $0.1-2$ & Ashworth and Ferguson [1989] \\
0.047 & -0.88 & 73 & $0.04-1.2$ & Ferguson et al. [1989] \\
0.049 & -0.69 & $18-32$ & $0.15-3.2$ & Ashworth et al. [1992] \\
0.044 & -0.59 & 56 & $1.57-3.13$ & This study \\
\hline
\end{tabular}

ity of the parameters in the shear stress criterion to different estimates of these characteristic particle sizes in Dupuyer Creek (Table 4).

[29] We suggest that a surface-area-based pebble count is the correct procedure for estimating the stream bed size distribution and $\mathrm{D}_{50}$ in flow competence analyses. However, there is considerable variability in the exact technique used in the field to select the particles for measurement, and different variants of the pebble count will produce different results [Marcus et al., 1995; Wohl et al., 1996; Kondolf, 1997; Bunte and Abt, 2001a, 2001b]. At the current time there is little consensus as to which form of pebble count should be employed in a flow competence analysis. Here the result of using a stream bed surface $\mathrm{D}_{50}$ estimate from a reach-scale pebble count $(42 \mathrm{~mm})$ is compared with that obtained using a $\mathrm{D}_{50}$ estimate restricted to the riffle where bed load was sampled $(56 \mathrm{~mm})$ as shown in Table 4 . The reach-scale pebble count gives a finer stream bed size distribution because of the inclusion of finer deposits around pool regions and bar features which are absent from the sampled riffle. However, the resulting values of the critical dimensionless shear stress for the $\mathrm{D}_{50}(\theta$ in Table 4$)$ are not significantly different at the $95 \%$ confidence level.

[30] Difficulty in estimating the surface size distribution $\left(D_{50}\right)$ is caused not only by the spatial variability, but the potential temporal variability during the passage of a flood hydrograph. Pebble counts undertaken before and after the floods sampled in this study showed that the $D_{50}$ size decreased from 56 to $48 \mathrm{~mm}$ after the second flood. While there is evidence of persistence in the surface size distribution during floods in other settings [Andrews and Erman, 1986; Wilcock and DeTemple, 2005], it seems highly probable that the $\mathrm{D}_{50}$ is fluctuating in our study riffle in response to the size distribution of sediment supplied from upstream and unsteady flow dynamics [De Jong and Ergenzinger, 1992; De Jong, 1993; Ergenzinger et al.,

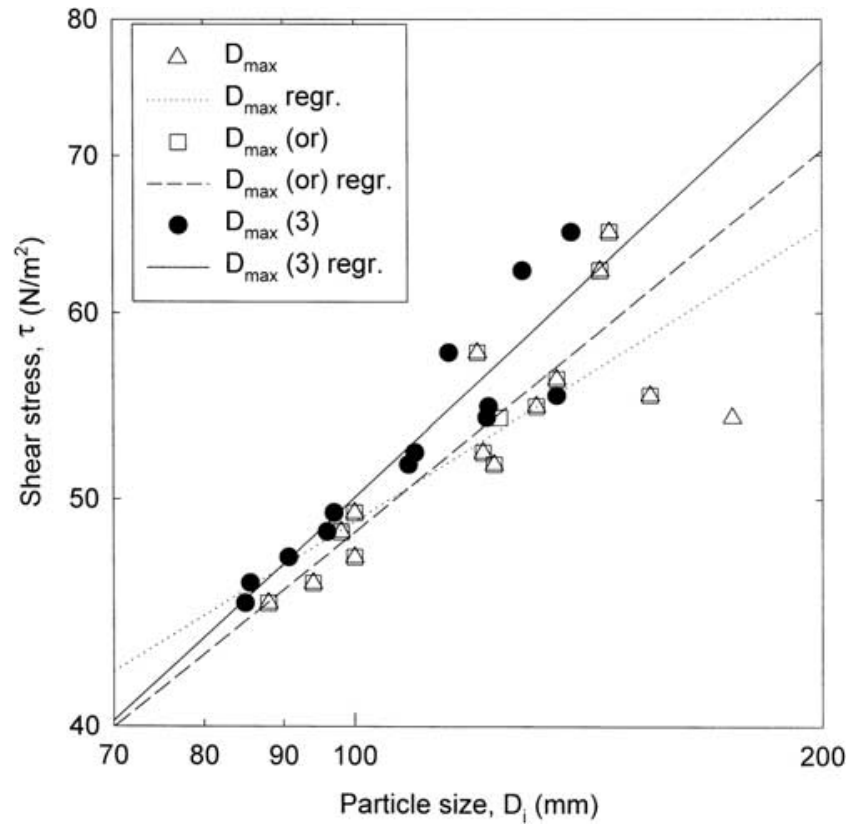

Figure 6. Flow competence curves of the form $\tau=\mathrm{aD}_{\mathrm{i}}^{\mathrm{b}}$ for $\mathrm{D}_{\max }=$ maximum particle size; $\mathrm{D}_{\max }($ or $)=$ maximum size with outlier removed; and $\mathrm{D}_{\max }(3)=$ mean of the three largest particle sizes. Regression equations are given in Table 4.

1994]. As described in section 3, Dupuyer Creek is a very dynamic system with poor armor layer development.

[31] When sampling for the maximum particle size in transport there is concern that extreme values and outliers can distort the flow competence relationship and render it unreliable [Komar and Carling, 1991; Wilcock, 1992]. To address this concern, the mean of the largest three to five particles captured has been used to represent the maximum size in transport [Carling, 1983]. In this analysis, flow competence was examined for the following definitions of maximum particle size (Figure 6):

[32] $\mathrm{D}_{\max }=$ absolute maximum particle size captured in each sample group.

[33] $\mathrm{D}_{\max }$ (or) = absolute maximum particle size captured in each sample group, but with the removal of a suspected outlier from one sample group (175 $\mathrm{mm}$ particle size in group 4).

[34] $\mathrm{D}_{\max }(3)=$ arithmetic mean of the three largest particles captured in each sample group, excluding the suspected outlier.

Table 4. Sensitivity of Flow Competence Curves to the Values Assumed for Maximum Size Entrained and Stream Bed $\mathrm{D}_{50}$ in Relationship Between Shear Stress $\tau$ and Maximum Size Entrained $\mathrm{D}_{\mathrm{i}}$ and Relationship Between Critical Dimensionless Shear Stress $\theta_{c i}$ and Relative Particle Size $\mathrm{D}_{\mathrm{i}} / \mathrm{D}_{50}{ }^{\mathrm{a}}$

\begin{tabular}{|c|c|c|c|c|c|c|c|}
\hline \multicolumn{4}{|c|}{$\tau=a \mathrm{D}_{\mathrm{i}}^{b}$} & \multicolumn{4}{|c|}{$\theta_{\mathrm{ci}}=\theta\left(\mathrm{D}_{\mathrm{i}} / \mathrm{D}_{50}\right)^{x}$} \\
\hline $\mathrm{D}_{\mathrm{i}}$ & $a$ & $b$ & $\mathrm{R}^{2}$ & $\theta, \mathrm{D}_{50}=56 \mathrm{~mm}$ & $\theta, \mathrm{D}_{50}=42 \mathrm{~mm}$ & $x$ & $\mathrm{R}^{2}$ \\
\hline $\mathrm{D}_{\max }$ & 7.24 & 0.41 & 0.63 & $0.044(0.040,0.047)^{\mathrm{b}}$ & $0.052(0.048,0.055)^{\mathrm{b}}$ & -0.59 & 0.77 \\
\hline $\mathrm{D}_{\max }$ (or) & 4.05 & 0.54 & 0.79 & $0.040(0.037,0.043)^{\mathrm{b}}$ & $0.046(0.043,0.049)^{\mathrm{b}}$ & -0.46 & 0.73 \\
\hline $\mathrm{D}_{\max }(3)$ & 2.94 & 0.62 & 0.85 & $0.040(0.037,0.043)^{\mathrm{b}}$ & $0.045(0.042,0.047)^{\mathrm{b}}$ & -0.38 & 0.69 \\
\hline
\end{tabular}




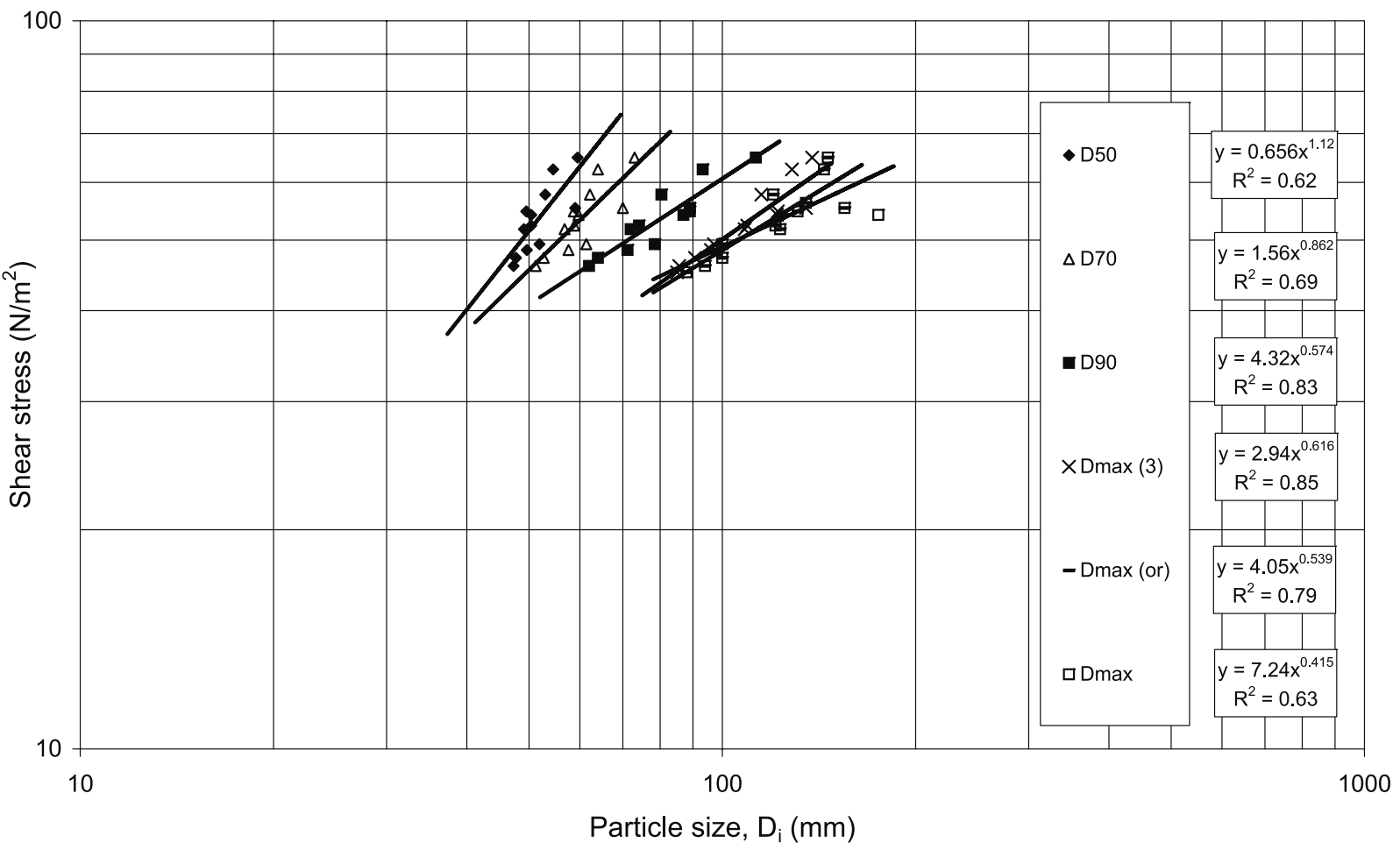

Figure 7. Flow competence relationships of the form $\tau=\mathrm{aD}_{\mathrm{i}}^{\mathrm{b}}$ for bed load percentiles $\mathrm{D}_{50}, \mathrm{D}_{70}$, and $\mathrm{D}_{90}$; maximum particle size, $\mathrm{D}_{\max }$; maximum size with outlier removed, $\mathrm{D}_{\max }$ (or); and mean of the three largest particle sizes, $\mathrm{D}_{\max }(3)$. Regression lines are extended $\pm 10 \mathrm{~mm}$ on the $x$ axis. Regression equations show that the exponent $b$ becomes larger (steeper slope) as one moves from the $\mathrm{D}_{\max }$ to $\mathrm{D}_{\max }(3)$ and again from $\mathrm{D}_{90}$ to $\mathrm{D}_{50}$ percentiles.

[35] Table 4 shows that the relationship between shear stress, $\tau$, and maximum particle size, $\mathrm{D}_{\mathrm{i}}$, improves when first the outlier is removed, and then the mean of the three largest particles is considered. However, the corresponding relationships for the dimensionless shear stress, $\theta_{\text {ci }}$, show a slight decrease in the R-squared value. The exponent $x$ in the dimensionless shear stress equation is particularly sensitive to the definition of maximum particle size in transport. Discounting the outlier and taking the mean of the three largest particles results in a fitted flow competence curve with values for the coefficient and exponent even further removed from those obtained by previous workers (Table 3). This is shown in Figure 6 by the steeper regression line for the mean of the three largest particles, compared to the other definitions of maximum particle size.

[36] Flow competence relationships based on the single largest particle in each sample are very sensitive to the influence of outliers. More consistent results may be achieved if the mean of the three largest particles captured is used to model flow competence. Values for the second largest particle size were very close to the mean values of the three largest particles, giving almost identical flow competence relationships. The value of $\theta$, the dimensionless shear stress coefficient for the median particle size, is by definition dependent on our estimate of the stream bed surface $\mathrm{D}_{50}$, but also our estimate of the maximum size entrained as shown in Table 4. However, less certainty can be placed on the estimates of $\theta$, compared to $x$, because they were derived by extrapolation outside the range of particle sizes sampled.

\subsubsection{Bed Load Percentile Relationships}

[37] In determining flow competence, the problems associated with using an extreme value of the transport grainsize distribution have led to the consideration of alternative definitions [Wilcock, 1992]. Flow competence may be defined for the central tendency of the bed load size distribution such as the $\mathrm{D}_{50}$, or some coarse percentile that is established by a reasonable number of grains. The following formula may be used to examine flow competence curves in terms of the changing caliber of sampled bed load percentiles with varying flow stress:

$$
\tau=a \mathrm{D}_{\mathrm{i}}^{b}
$$

where $\tau$ is the shear stress required to bring the bed load percentile $D_{i}$ to a given size. This analysis was undertaken with the Dupuyer Creek data by determining bed load size distribution percentiles for each sample group as a whole, ranging from $D_{50}$ to $D_{\max }$ (here bed load truncated at $38 \mathrm{~mm}$ ). Regression analysis was used to determine the coefficient $a$ and exponent $b$, and the results are summarized in Figure 7.

[38] The $\mathrm{D}_{\max }$ competence curve for the Dupuyer Creek data is similar in terms of the coefficient $a$ and exponent $b$ to the reported values for Oak Creek, a rainfall-dominated gravel bed stream in Oregon (Milhous [1973], as analyzed by Komar and Carling [1991]). The bed load percentiles $\left(D_{50}\right.$ to $\left.D_{90}\right)$ cannot be directly compared because of the truncation of Dupuyer Creek data at $38 \mathrm{~mm}$. However, we can compare the trends in how the slope exponent, $b$, varies 


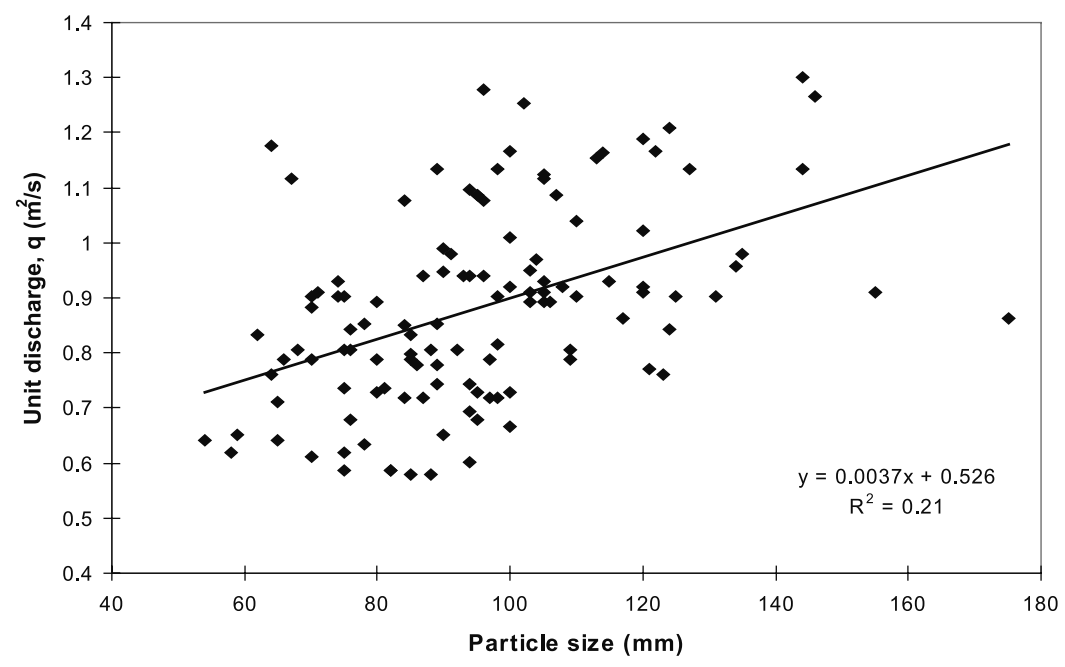

Figure 8. Relationship between unit discharge and the maximum particle size, $D_{\max }$, for the 120 individual bed load samples taken during the two floods of 6-10 May and 6-11 June 1995.

between bed load percentiles. For Dupuyer Creek, the slope increases toward the lower percentiles, indicating that bed load percentiles closer to the $D_{50}$ are less sensitive to changes in shear stress compared with higher bed load percentiles. The same trend was found by Bunte $[1992 \mathrm{~b}$, 1996] who measured coarse bed load in a snowmeltdominated gravel bed stream using a similar sampler to the one we have used. However, the opposite trend is seen in the Oak Creek data [Komar and Carling, 1991], and the reason for the different trends may be due to the lack of armoring in Dupuyer Creek compared to Oak Creek (relatively fine subarmor and $\mathrm{a}_{50}$ of $20 \mathrm{~mm}$ ). In Oak Creek, increasing flows would release more and more of the subsurface fines, causing the medium size fractions to increase while the coarse sizes remain less changed. In contrast, there is less fine sediment to be released at Dupuyer Creek.

[39] Flow competence curves for Dupuyer Creek show best fit between shear stress and the mean of the three largest particles $\left(D_{\max }(3)\right.$ in Figure $\left.7, R^{2}=0.85\right)$, closely followed by the relationship for coarse bed load $\mathrm{D}_{90}\left(\mathrm{R}^{2}=\right.$ 0.83). In Oak Creek the pattern is very similar, with lowest $\mathrm{R}$-squared values for the $\mathrm{D}_{50}$ and $\mathrm{D}_{\max }$ sizes and the best fit for the $D_{90}\left(R^{2}=0.81\right)$. This suggests that a coarse bed load percentile such as the $\mathrm{D}_{90}$ or the mean of the three largest particles would be the most suitable parameter to model in flow competence analyses. For Dupuyer Creek these coarse percentiles are also more sensitive to changes in flow stress than the bed load $\mathrm{D}_{50}$, at least over the range of flows sampled. In other words, changes in flow shear stress produce a greater response in the maximum bed load particle sizes $\left(\mathrm{D}_{\max }(3)\right)$ than the median bed load particle size $\left(\mathrm{D}_{50}\right)$.

\subsection{Critical Unit Discharge}

[40] In this section we show the results of applying the critical unit discharge method through equations (4) to (6) in the evaluation of flow competence. As in the previous section, we present the results for flow competence as defined by maximum particle sizes, followed by an examination of the sensitivity of flow competence relationships to estimated particle sizes.

\subsubsection{Maximum Particle Size Relationships}

[41] When unit discharge is plotted against the maximum particle size for each individual bed load sample, a wide range of scatter is seen (Figure 8) similar to the shear stress plot (Figure 3). The relationship between maximum particle size in each sample group and the mean unit discharge shows much less scatter, and a power function is fitted with an R-squared value of 0.66 (Figure 9). Also plotted in Figure 9 is the empirical relationship for uniform sediments given by equation (4), which Bathurst [1987] suggested could be used to predict the critical flow for entrainment of the reference particle size $\left(\mathrm{D}_{50}\right)$ in mixed-sized sediments.

[42] However, for Dupuyer Creek equation (4) does not predict the critical flow for the entrainment of the reference particle size $\left(D_{50}\right)$, because the intersection of the two relationships at $14 \mathrm{~mm}$ is a significant departure from the $\mathrm{D}_{50}$ value of $56 \mathrm{~mm}$. Equation (4) predicts the critical flow for entrainment of the $\mathrm{D}_{50}$ at Dupuyer Creek to be $1.08 \mathrm{~m}^{2} / \mathrm{s}$, whereas we sampled particle sizes as large as the $\mathrm{D}_{90}$ at such flows. By extrapolating our fitted flow competence curve to smaller particle sizes (Figure 10), we predict that the $\mathrm{D}_{50}$ will be entrained at a flow of $0.43 \mathrm{~m}^{2} / \mathrm{s}(95 \%$ confidence limits: $0.22,0.65 \mathrm{~m}^{2} / \mathrm{s}$ ), showing that for Dupuyer Creek coarse bed load is entrained at much lower flows than those predicted by equation (4).

[43] The relationship between critical unit discharge and relative particle size is modeled through regression to determine the exponent $b$ in equation (5), represented by the line gradient (Figure 10). The $b$ value of 0.84 obtained for Dupuyer Creek is 2-4 times greater than those values found by Bathurst [1987] for the Roaring River, and greater than other reported values summarized by Ferguson [1994], indicating greater size selectivity in bed load transport for Dupuyer Creek. The higher gradient in the critical unit discharge particle size relationship is one reason why the relationships in Figure 9 intersect well below the measured $\mathrm{D}_{50}$. In section 5.2.2 we consider the difference in bed load sampling methods between studies, which has also been shown to influence the slope of flow competence curves [Bunte et al., 2004].

[44] At Dupuyer Creek we found that the value of $b$ obtained through regression analysis on the data (0.84) was 


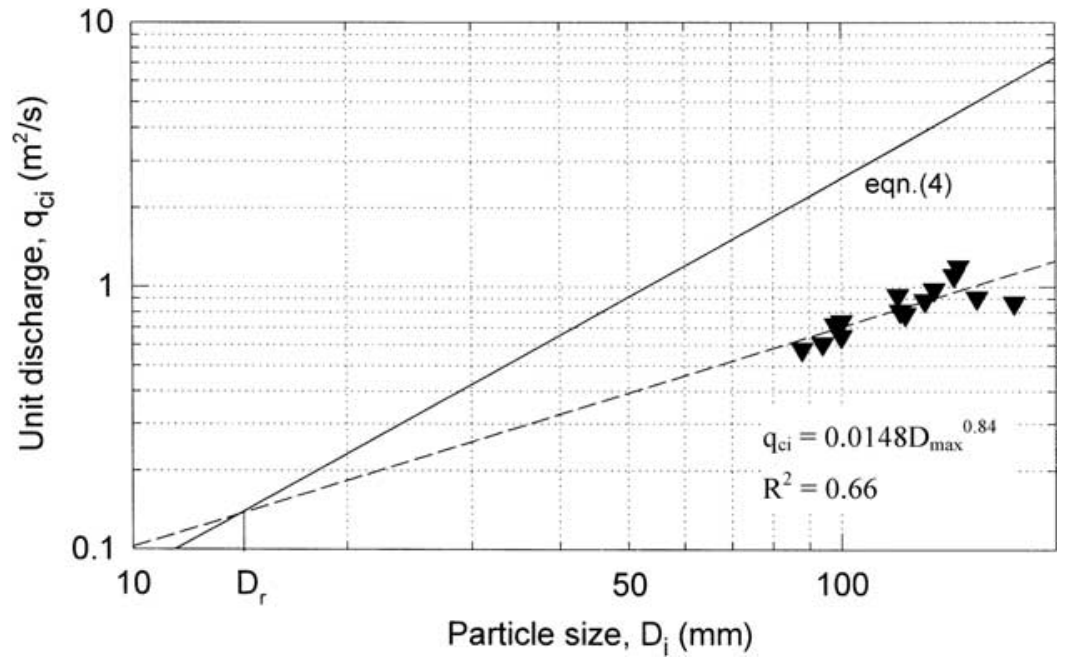

Figure 9. Critical unit discharge against the maximum particle size entrained, $\mathrm{D}_{\max }$, for the sample group data (regression shown). Equation (4) represents the relationship for uniform sediments. The two relationships intersect at $14 \mathrm{~mm}$, which is much finer than the $\mathrm{D}_{50}$ of $56 \mathrm{~mm}$.

much greater than the value of 0.36 obtained through equation (6). This is likely due to factors other than the $\mathrm{D}_{84} / \mathrm{D}_{16}$ sorting ratio which influence the slope of the flow competence curve. Differences in climate, runoff regime, and sediment supply, all influence stream bed characteristics such as the degree of armoring and imbrication. Dupuyer Creek is notable for the high sediment supply, the looseness of the stream bed particles, and the lack of armoring or imbrication. This could produce higher size selectivity by allowing smaller particles to be entrained from the loose matrix, whilst movement of larger particles remains marginal. A tightly packed stream bed, or one that exhibits greater structure, increases the interdependence between particles and narrows the range of discharge over which all particles are entrained. This reasoning is in agreement with the work of Barry et al. [2004] in their discussion on the variability of bed load rating curve exponents. The relatively shorter duration of intermediate flows in rain- fall-dominated climates (i.e., flashier hydrograph) leads to a decrease in the degree of armoring [Laronne and Reid, 1993; Lisle et al., 2000] and greater size selectivity, whereby the stream bed size distribution is entrained over a relatively wider range in discharge.

\subsubsection{Sensitivity to Estimated Particle Sizes}

[45] The sensitivity of parameters in the unit discharge criterion to different estimates of the characteristic particle sizes was also examined for the Dupuyer Creek data (Table 5). Again the result of using a stream bed $D_{50}$ estimate from a reach-scale pebble count $(42 \mathrm{~mm})$ is compared with that obtained using a $\mathrm{D}_{50}$ estimate restricted to the riffle where bed load was sampled $(56 \mathrm{~mm})$. Flow competence was examined for the same definitions of maximum particle size as given before in section 5.1.2.

[46] In a similar pattern to the shear stress analysis, the degree of fit of the flow competence curve improves when first the outlier is removed and then the mean of the three

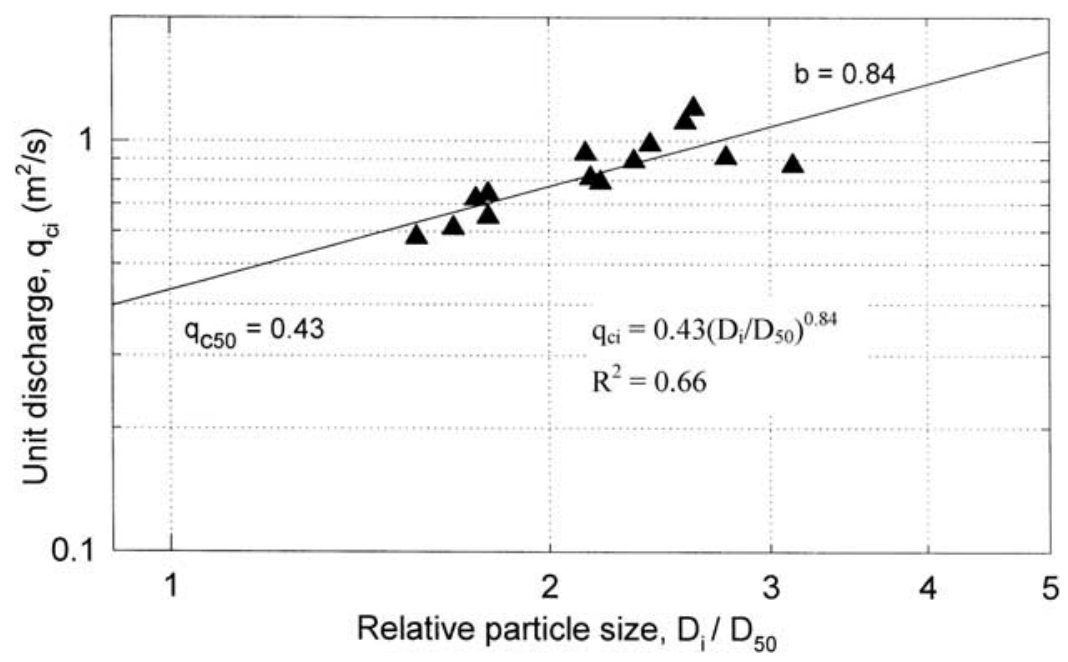

Figure 10. Critical unit discharge against relative particle size. Equation (5) is represented by the regression line, with slope $b=0.84$. The critical unit discharge for the surface $\mathrm{D}_{50}$ is estimated to be $0.43 \mathrm{~m}^{2} / \mathrm{s}\left(95 \%\right.$ confidence limits: 0.22 and $\left.0.65 \mathrm{~m}^{2} / \mathrm{s}\right)$. 
Table 5. Sensitivity of Flow Competence Curves to the Values Assumed for Maximum Size Entrained and Stream Bed $D_{50}$ in the Relationship Between Critical Unit Discharge $\mathrm{q}_{\mathrm{ci}}$ and Maximum Size in Transport $\mathrm{D}_{\mathrm{i}}{ }^{\mathrm{a}}$

\begin{tabular}{|c|c|c|c|c|c|c|}
\hline \multirow[b]{2}{*}{$\mathrm{D}_{\mathrm{i}}$} & \multirow[b]{2}{*}{$b$} & \multirow[b]{2}{*}{$\mathrm{R}^{2}$} & \multicolumn{2}{|c|}{$\mathrm{D}_{50}=56 \mathrm{~mm}$} & \multicolumn{2}{|c|}{$\mathrm{D}_{50}=42 \mathrm{~mm}$} \\
\hline & & & $\mathrm{q}_{\mathrm{c} 50}$, equation (4) & $\mathrm{q}_{\mathrm{c} 50}$, from Dupuyer Regression & $\mathrm{q}_{\mathrm{c} 50}$, equation (4) & $\mathrm{q}_{\mathrm{c} 50}$, from Dupuyer Regression \\
\hline $\mathrm{D}_{\max }$ & 0.84 & 0.66 & 1.08 & $0.43(0.22,0.65)^{\mathrm{b}}$ & 0.70 & $0.34(0.12,0.56)^{\mathrm{b}}$ \\
\hline $\mathrm{D}_{\max }$ (or) & 1.08 & 0.82 & 1.08 & $0.37(0.21,0.53)^{\mathrm{b}}$ & 0.70 & $0.27(0.11,0.43)^{\mathrm{b}}$ \\
\hline $\mathrm{D}_{\max }(3)$ & 1.22 & 0.89 & 1.08 & $0.36(0.24,0.49)^{\mathrm{b}}$ & 0.70 & $0.26(0.13,0.38)^{\mathrm{b}}$ \\
\hline
\end{tabular}

${ }^{\mathrm{a}}$ Critical Unit Discharge: $\mathrm{q}_{\mathrm{ci}}=\mathrm{q}_{\mathrm{c} 50}\left(\mathrm{D}_{\mathrm{i}} / \mathrm{D}_{50}\right)^{b}$. Units for $\mathrm{q}_{\mathrm{ci}}$ are $\mathrm{m}^{2} / \mathrm{s}$.

${ }^{\mathrm{b}}$ The $95 \%$ confidence limits.

largest particles is considered (Table $5, \mathrm{R}^{2}$ increases from 0.66 to 0.89 ). The slope exponent, $b$, increases from 0.84 to 1.22 (Figure 11). Estimates of $b$ are not dependent on our estimate of surface $D_{50}$, but they are shown to be very sensitive to how the maximum particle size is defined, and therefore to sampling methods and strategy. The wide range in values for $b$ in the literature $(0.2$ to 1.2$)$ may be attributed, in part, to different sampling methods and definitions of $\mathrm{D}_{\max }$, although variability in the grain sorting and packing characteristics of stream channels is likely to play a dominant role.

[47] In terms of $Q$ versus $D_{\max }$ flow competence curves, we would expect relatively steeper slopes when a HelleySmith sampler is used, given that the $\mathrm{D}_{\max }$ would be underestimated as a result of limited sampler intake size [Sterling and Church, 2002; Vericat et al., 2006] and limited sampling time [Bunte and Abt, 2005]. Bunte et al. [2004] have confirmed the tendency of Helley-Smith samplers to produce steeper $\mathrm{Q}$ versus $\mathrm{D}_{\max }$ competence curves when compared with portable bed load traps. However, these sampler effects cannot explain the relatively low values of slope ( $b=0.2$ to 0.4 ) obtained through Helley-Smith sampling in the boulder bed Roaring River [Bathurst, 1987]. In the gravel bed Oak Creek, bed load was sampled using a vortex tube [Milhous, 1973], giving a value of 1.22 for $b$ [Komar, 1989], which is the same value as found at Dupuyer Creek when maximum particle size is defined by the three largest particles $\left(D_{\max }(3)\right.$, Table 5).

[48] For each definition of maximum particle size assumed at Dupuyer Creek, the observed flow competence curves do not intersect the empirical flow competence curve for uniform sediments even close to the surface $\mathrm{D}_{50}$ (Figure 11). Table 5 shows the large disparity in predicted values for $\mathrm{q}_{\mathrm{c} 50}$ between equation (4) and the regression fits on the Dupuyer Creek data. Even when we assume a smaller particle size for the $\mathrm{D}_{50}$ value, the estimate from equation (4) lies well outside of the $95 \%$ confidence limits for the Dupuyer Creek regression fit.

\subsection{Sample Mass Variability}

[49] Wilcock [1992] criticized the classical concept of flow competence, and suggested the relationships are sensitive to the effect of sample mass that tends to vary widely in bed load samples. In this section we analyze the effects of variable sample mass on flow competence curves. As shown in Table 2, sample mass is highly variable between sample groups. We examine the degree to which flow competence relationships are explained by the fact that larger samples at higher flows have a greater probability of containing the larger particles in the coarse tail of the bed load size distribution.
[50] The Dupuyer Creek bed load data show correlations between sample mass and flow variables, with Pearson correlation coefficients of 0.81 and 0.83 for unit discharge and shear stress respectively (99\% significance level). These correlations are inevitable because higher rates of bed load transport during high flows produce larger samples, even when sample time is greatly reduced. The result is that we find significant correlations between sample mass and the caliber of bed load sampled (Table 6).

[51] Partial correlation coefficients are used to determine the true relationship between flow strength and bed load percentiles by controlling for the variability of sample mass. The correlation coefficients are lower when calculated in this way, but many are still significant at the 99 percent level. This indicates that the flow competence relationships derived between flow strength (shear stress and unit discharge) and bed load caliber remain valid even after accounting for bias due to variation in sample mass. Partial correlation coefficients improve greatly when the outlier observation is removed from the $D_{\max }$ data series. Peak coefficient values occur with the bed load $\mathrm{D}_{90}$, indicating

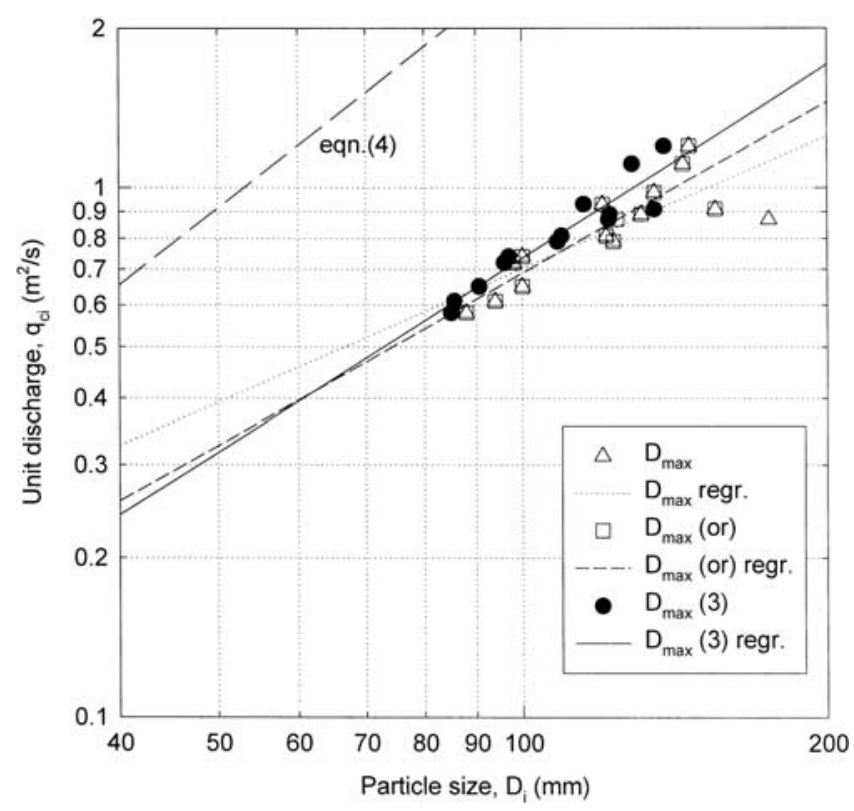

Figure 11. Flow competence relationships of the form $\mathrm{q}_{\mathrm{ci}}=$ $\mathrm{aD}_{\mathrm{i}}^{\mathrm{b}}$ for $\mathrm{D}_{\max }=$ maximum particle size; $\mathrm{D}_{\max }($ or $)=$ maximum size with outlier removed; and $\mathrm{D}_{\max }(3)=$ mean of the three largest particle sizes. Equation (4) for uniform sediments is also plotted. Regression equations are given in Table 5. 
Table 6. Correlation and Partial Correlation Coefficients to Examine the Effect of Sample Mass Variability on Flow Competence Relationships Based on Shear Stress and Unit Discharge

\begin{tabular}{|c|c|c|c|c|c|}
\hline \multirow{2}{*}{$\begin{array}{l}\text { Bed Load } \\
\text { Percentile }\end{array}$} & \multicolumn{3}{|c|}{ Pearson Correlation Coefficients } & \multicolumn{2}{|c|}{$\begin{array}{l}\text { Partial Correlation Coefficients } \\
\text { Controlling for Sample Mass }\end{array}$} \\
\hline & Shear Stress & Unit Discharge & Sample Mass & Shear Stress & Unit Discharge \\
\hline $\mathrm{D}_{50}$ & 0.79 & 0.81 & 0.65 & $0.61^{\mathrm{a}}$ & 0.67 \\
\hline$D_{60}$ & 0.80 & 0.82 & 0.70 & $0.53^{\mathrm{a}}$ & $0.59^{\mathrm{a}}$ \\
\hline $\mathrm{D}_{70}$ & 0.82 & 0.85 & 0.73 & $0.55^{\mathrm{a}}$ & $0.63^{\mathrm{a}}$ \\
\hline $\mathrm{D}_{75}$ & 0.85 & 0.87 & 0.74 & $0.61^{\mathrm{a}}$ & 0.69 \\
\hline $\mathrm{D}_{80}$ & 0.85 & 0.88 & 0.70 & $0.68^{\mathrm{a}}$ & 0.76 \\
\hline $\mathrm{D}_{90}$ & 0.91 & 0.94 & 0.76 & 0.78 & 0.87 \\
\hline $\mathrm{D}_{95}$ & 0.86 & 0.88 & 0.70 & 0.72 & 0.78 \\
\hline $\mathrm{D}_{\max }(3)$ & 0.91 & 0.92 & 0.84 & 0.66 & 0.70 \\
\hline $\mathrm{D}_{\max }$ (or) & 0.87 & 0.88 & 0.74 & 0.67 & 0.71 \\
\hline $\mathrm{D}_{\max }$ & 0.73 & 0.74 & 0.65 & $0.45^{\mathrm{a}}$ & $0.48^{\mathrm{a}}$ \\
\hline
\end{tabular}

${ }^{a}$ At the $95 \%$ significance level (one-tailed test); all other coefficients are at the $99 \%$ significance level.

coarse tail variables are more reliable than $\mathrm{D}_{\max }$ for flow competence modeling.

\subsection{Comparison of Shear Stress and Unit Discharge Approaches}

[52] Plots of critical shear stress and critical unit discharge against maximum sampled bed load sizes both showed good correlations for the sample groups (Figures 4 and 9). For maximum particle sizes or coarse bed load percentiles, flow competence curves were established using dimensionless critical shear stress (equation (3) and Figure 5). Variation in the dimensionless shear stress coefficient $\theta$ appears to relate to relative particle size in the manner suggested by Andrews [1983], although the significance of the hiding and exposure adjustment decreases toward smaller bed load percentiles. For maximum particle size curves, the value derived for $\theta$ is just within the range of values seen in other studies on gravel bed streams, but the value for the exponent $x$ appears outside of the range of published values (Table 3), especially when $\mathrm{D}_{\max }(3)$ is taken as the definition of maximum particle size (Table 4). Therefore without coarse bed load sampling to determine suitable values for $\theta$ and $\mathrm{x}$, it would be difficult to make accurate predictions of flow competence using the critical shear stress approach.

[53] With the unit discharge criterion a further problem emerges. The method assumes that the critical unit discharge for entrainment of the median particle size in mixed sediments can be estimated by equation (4). However, coarse bed load sampling at Dupuyer Creek showed that equation (4) cannot be applied in this manner. The equation is semiempirical and based on flume experiments using uniform sediments over a limited range of particle sizes (3$44 \mathrm{~mm}$ ), which may explain why the equation did not give realistic predictions for Dupuyer Creek.

[54] We found coarse bed load percentile sizes and maximum particle sizes were both highly correlated to the flow variables of shear stress and unit discharge, even after sample size effects were removed (Table 6). The difficulty lies in determining suitable values for the coefficients and exponents in the empirical flow competence equations (3) and (5). In the shear stress criterion we must set values for $\theta$ and $x$ in equation (3). In the unit discharge criterion we would have to revise equation (4), and set the value for $b$ in equation (5). In the absence of sampled bed load data for a given gravel bed stream, we can have little confidence in predicting the prevailing flow competence curves. This study has shown that coarse bed load sampling over two major floods allowed us to establish the coefficient $\theta$ and exponent $x$ in the shear stress criterion, within somewhat wide confidence limits due to the small number of sample groups (14) available. However, in attempting to use the unit discharge criterion we found that there were major conceptual problems in the application of equation (4). Therefore the shear stress approach is more suitable for the prediction of flow competence curves at Dupuyer Creek.

\section{Discussion}

[55] The Dupuyer Creek data has been used to demonstrate the relative performances of the critical shear stress and critical unit discharge approaches in modeling flow competence. The purpose of flow competence modeling is to enable the following questions to be addressed for stream channels composed of mixed size sediments:

[56] 1. For maximum particle sizes in transport, (1) What critical flow is required to transport a given particle size? (2) What is the maximum particle size that will be transported at a given flow?

[57] 2. For percentiles in the bed load size distribution, (1) What critical flow is required to bring a given bed load percentile to a given size? (2) What is the size attained for a given bed load percentile at a given flow?

[58] The Dupuyer Creek data shows that flow competence relationships can be formulated and used to answer the above questions. However, it is important to stress that these relationships apply only to the range of flows and particle sizes for which they were developed. Observations of bed load transport behavior in Dupuyer Creek suggest that major discontinuities may exist in flow competence curves. At approximately $0.58 \mathrm{~m}^{2} / \mathrm{s}$ or $45 \mathrm{~N} / \mathrm{m}^{2}$ on the falling limb of the May flood, coarse bed load flux had dropped to a marginal rate $(0.001 \mathrm{~kg} / \mathrm{s} / \mathrm{m}$ for $>38 \mathrm{~mm}$ fraction) and we were just able to operate a handheld $76 \mathrm{~mm}$ nozzle Helley-Smith sampler in addition to the large-frame sampler. At a similar flow shortly before, the large-frame sampler (mesh $32 \mathrm{~mm}$ ) had captured particles up to $88 \mathrm{~mm}$ in size, but now no longer captured bed load, while the Helley-Smith captured particles up to $35 \mathrm{~mm}$ in size. Although we are comparing the results of two different samplers here, it suggests that the maximum particle size 
entrained was suddenly reduced from 88 to $35 \mathrm{~mm}$ (surface $\mathrm{D}_{70}$ to $\mathrm{D}_{25}$ ). Further sampling is needed to confirm this bed load behavior at Dupuyer Creek.

[59] Without an intensive bed load sampling scheme, the difficulty is in knowing whether any such discontinuity may occur in the flow competence curve, in addition to the calibration of the coefficient and exponent in the relationship. Our ability to predict flow competence curves in gravel bed streams will be strongly limited by the variability of local stream channel characteristics, and our ability to accurately characterize the stream bed size distribution.

[60] Even when bed load sampling is undertaken, the maximum particle sizes obtained depend on the sampling device used [e.g., Bunte et al., 2004] and the sampling strategy followed. Determination of optimum sample duration remains problematic because of the unsteady and pulsing characteristics of bed load transport [e.g., Bunte and $A b t, 2005]$. There is currently no consensus on suitable standards for bed load sampling and characterization of stream bed size distributions in the development of flow competence curves, although it has been suggested that a few observations of small transport rates may be the most effective approach to calibrate transport formulae [Wilcock, 2001]. Use of the portable large-frame bed load sampler in this study demonstrates the potential of alternative sampling devices, which are needed to develop, validate, and calibrate flow competence criteria and sediment transport formulae.

\section{Conclusions}

[61] For the gravel bed Dupuyer Creek, flow competence curves can be usefully employed over the range of particle sizes $\left(88-175 \mathrm{~mm}\right.$ or surface $\left.\mathrm{D}_{70}-\mathrm{D}_{95}\right)$ and flows $(0.58-$ $1.2 \mathrm{~m}^{2} / \mathrm{s}$ ) for which transport was shown to be size selective. Model coefficients and exponents derived for the shear stress criterion are close to the range of values published for other gravel bed streams, although with a slightly lower dependence on relative particle size and the hiding/exposure effect. Equation (4) in the unit discharge criterion could not be used to predict entrainment of the surface $\mathrm{D}_{50}$ size. The equation coefficient $(0.15)$ or exponent for the water surface slope term $(-1.12)$ would need to be redefined. Therefore the shear stress criterion is recommended for estimating flow competence at Dupuyer Creek.

[62] Consideration must be given to the presence of outliers in developing flow competence curves for sampled maximum particle sizes. Removal of a single outlier in the Dupuyer Creek data has a very large effect on the regression relationship for maximum particle sizes. Modeling the mean of the three largest particles sampled, $D_{\max }(3)$, reduces the influence of possible outliers. Additionally, the effects of sample mass variability are much reduced for the $D_{\max }(3)$ variable, suggesting this could be a more suitable variable with which to model flow competence. Coarse bed load grain sizes such as the $\mathrm{D}_{\max }(3)$ variable are more sensitive to changes in flow strength than the median bed load grain size, and therefore are superior parameters for flow competence modeling. Significant flow competence relationships have been derived for a wide range of bed load grain sizes from the $D_{50}$ to $D_{\max }$. The most useful relationship will depend on the particular problem to which modeling is being applied.
[63] Acknowledgments. This work was funded by the College of Forestry and Conservation, University of Montana, with additional support provided by McEntire Stennis, Plum Creek Timber Company, and Boone and Crockett Wildlife Conservation Program. We are grateful for the detailed and insightful comments made by three anonymous reviewers.

\section{References}

Andrews, E. D. (1983), Entrainment of gravel from naturally sorted riverbed material, Geol. Soc. Am. Bull., 94, 1225-1231.

Andrews, E. D., and D. C. Erman (1986), Persistence in the size distribution of surficial bed material during an extreme snowmelt flood, Water Resour. Res., 22, 191-197.

Ashiq, M., and J. C. Bathurst (1999), Comparison of bed load sampler and tracer data on initiation of motion, J. Hydraul. Eng., 125, 661-664.

Ashworth, P. J., and R. I. Ferguson (1989), Size-selective entrainment of bed load in gravel bed streams, Water Resour. Res., 25, 627-634.

Ashworth, P. J., R. I. Ferguson, P. E. Ashmore, C. Paola, D. M. Powell, and K. L. Prestegaard (1992), Measurements in a braided river chute and lobe: 2 . Sorting of bed load during entrainment, transport and deposition, Water Resour. Res., 28, 1887-1896.

Barry, J. J., J. M. Buffington, and J. G. King (2004), A general power equation for predicting bed load transport rates in gravel bed rivers, Water Resour. Res., 40, W10401, doi:10.1029/2004WR003190.

Bathurst, J. C. (1987), Critical conditions for bed material movement in steep, boulder-bed streams, in Erosion and Sedimentation in the Pacific Rim, edited by R. L. Beschta et al., IAHS Publ., 165, 309-318.

Bathurst, J. C., W. H. Graf, and H. H. Cao (1987), Bed load discharge equations for steep mountain rivers, in Sediment Transport in Gravel-Bed Rivers, edited by C. R. Thorne, J. C. Bathurst, and R. D. Hey, pp. 453492, John Wiley, Hoboken, N. J.

Bunte, K. (1992a), Particle number grain-size composition of bed load in a mountain stream, in Dynamics of Gravel-Bed Rivers, edited by P. Billi et al., pp. 55-72, John Wiley, Hoboken, N. J.

Bunte, K. (1992b), Discussion of P. D. Komar and S.-M. Shih (1992), Equal mobility versus changing bedload grain sizes in gravel-bed streams, in Dynamics of Gravel-Bed Rivers, edited by P. Billi et al., pp. 93-96, John Wiley, Hoboken, N. J.

Bunte, K. (1996), Analyses of the temporal variation of coarse bedload transport and its grain size distribution (Squaw Creek, Montana, USA), 124 pp., Gen. Tech. Rep. RM-GTR-288, Rocky Mt. Res. Stn., USDA For. Serv., Fort Collins, Colo.

Bunte, K., and S. R. Abt (2001a), Sampling frame for improving pebble count accuracy in coarse gravel-bed streams, J. Am. Water Resour. Assoc., 37(4), 1001-1014.

Bunte, K., and S. R. Abt (2001b), Sampling surface and subsurface particlesize distributions in wadable gravel- and cobble-bed streams for analysis in sediment transport, hydraulics, and streambed monitoring, Gen. Tech. Rep. RMRS-GTR-74, 428 pp., Rocky Mt. Res. Stn., USDA For. Serv., Fort Collins, Colo.

Bunte, K., and S. R. Abt (2005), Effect of sampling time on measured gravel bed load transport rates in a coarse-bedded stream, Water Resour. Res., 41, W11405, doi:10.1029/2004WR003880.

Bunte, K., S. R. Abt, J. P. Potyondy, and S. E. Ryan (2004), Measurement of coarse gravel and cobble transport using portable bedload traps, J. Hydraul. Eng., 130, 879-893, doi:10.1061/ (ASCE)0733-9429 [2004]130:9 (879).

Carling, P. A. (1983), Threshold of coarse sediment transport in broad and narrow natural streams, Earth Surf. Processes Landforms, 8, 1-18.

Custer, S. G. (1992), A review of natural-gravel-transport-detection experiments at Squaw Creek, Montana, 1981-1991, in Channel Morphology and Flood Control: Proceedings of the Corps of Engineers Workshop on Steep Streams Held in Seattle, Washington, on 27-29 October 1992, U.S. Army Corps of Eng. Waterw. Exp. Stn. Misc. Pap. HL-94-4, pp. 3-1-3-28.

De Jong, C. (1993), Temporal and spatial interactions between river bed roughness, geometry, bed load transport and flow hydraulics in mountain streams: Examples from Squaw Creek, Montana (USA) and Lainbach/ Schmiedlaine, Upper Bavaria (Germany), Ph.D. thesis, 212 pp., Freie Univ. at Berlin, Germany.

De Jong, C., and P. Ergenzinger (1992), Unsteady flow, bed load transport and bed geometry responses in steep mountain torrents, in Proceedings of the 5th International Symposium on River Sedimentation and Sediment Management, 1, edited by P. Larsen and N. Eisenhauer, pp. 185-192, Univ. of Karlsruhe, Karlsruhe, Germany.

Dinehart, R. L. (1989), Dune migration in a steep, coarse-bedded stream, Water Resour. Res., 25, 911-923. 
Ergenzinger, P., and S. G. Custer (1983), Determination of bedload transport using naturally magnetic tracers: First experiences at Squaw Creek, Gallatin County, Montana, Water Resour. Res., 19, 187-193.

Ergenzinger, P., C. De Jong, and G. Christaller (1994), Interrelationships between bed load transfer and river-bed adjustment in mountain rivers: An example from Squaw Creek, Montana, in Process Models and Theoretical Geomorphology, edited by M. J. Kirkby, pp. 141-158, John Wiley, Hoboken, N. J.

Ferguson, R. I. (1994), Critical discharge for entrainment of poorly sorted gravel, Earth Surf. Processes Landforms, 19, 179-186.

Ferguson, R. I. (2003), The missing dimension: Effects of lateral variation on 1-D calculations of fluvial bedload transport, Geomorphology, 56, 1-14

Ferguson, R. I., K. L. Prestegaard, and P. J. Ashworth (1989), Influence of sand on gravel transport in a braided gravel bed river, Water Resour. Res., $25,635-643$.

Gilbert, G. K., and E. D. Murphy (1914), Transportation of debris by running water, U.S. Geol. Surv. Prof. Pap., 86, 263 pp.

Gomez, B., R. L. Naff, and D. W. Hubble (1989), Temporal variations in bed-load transport rates associated with the migration of bed-forms, Earth Surf. Processes Landforms, 14, 135-156.

Gomez, B., W. W. Emmett, and D. W. Hubbell (1991), Comments on sampling bedload in small rivers, paper presented at Fifth Federal Interagency Sedimentation Conference, Fed. Energy Regul. Comm., Washington, D. C., 18-21 March.

Hammond, F. D. C., A. D. Heathershaw, and D. N. Langhorne (1984), A comparison between Shields' threshold criterion and the movement of loosely packed gravel in a tidal channel, Sedimentology, 31, 51-62.

Helley, E. J., and W. Smith (1971), Development and calibration of a pressure-difference bedload sampler, U.S. Geol. Surv. Open File Rep., 73-108, 38 pp., Menlo Park, Calif.

Hey, R. D. (1979), Flow resistance in gravel-bed rivers, J. Hydraul. Div. Am. Soc. Civ. Eng., 105, 365-379.

Iseya, F., and H. Ikeda (1987), Pulsations in bed load transport rates induced by a longitudinal sediment sorting: A flume study using sand and gravel mixtures, Geogr. Ann., Ser. A, 69, 15-27.

Jackson, W. L., and R. L. Beschta (1982), A model of two-phase bedload transport in an Oregon Coast Range Stream, Earth Surf. Processes Landforms, 7, 517-527.

Komar, P. D. (1987), Selective grain entrainment by a current from a bed of mixed sizes: A reanalysis, J. Sediment. Petrol., 57, 203-211.

Komar, P. D. (1989), Flow-competence evaluations of the hydraulic parameters of floods: An assessment of the technique, in Floods: Hydrological, Sedimentological and Geomorphological Implications, edited by K. Beven and P. Carling, pp. 107-134, John Wiley, Hoboken, N. J.

Komar, P. D., and P. A. Carling (1991), Grain sorting in gravel-bed streams and the choice of particle sizes for flow-competence evaluations, Sedimentology, 38, 489-502.

Komar, P. D., and S. Shih (1992), Equal mobility versus changing bedload grain sizes in gravel-bed streams, in Dynamics of Gravel-Bed Rivers, edited by P. Billi et al., pp. 73-108, John Wiley, Hoboken, N. J.

Kondolf, G. M. (1997), Application of the pebble count: Notes on purpose, method, and variants, J. Am. Water Resour. Assoc., 33, 79-87.

Kuhnle, R. A., and J. B. Southard (1988), Bed load transport fluctuations in a gravel bed laboratory channel, Water Resour. Res., 24, 247-260.

Laronne, J. B., and I. Reid (1993), Very high rates of bedload sediment transport by ephemeral desert rivers, Nature, 366, 148-150.

Lenzi, M. A., V. D’Agostino, and P. Billi (1999), Bedload transport in the instrumented catchment of the Rio Cordon, part I: Analysis of bedload records, conditions and threshold of bedload entrainment, Catena, 36, $171-190$.

Leopold, L. B., and W. W. Emmett (1976), Bed load measurements, East Fork River, Wyoming, Proc. Natl. Acad. Sci. U.S.A., 73, 1000-1004.

Lisle, T. E., J. M. Nelson, J. Pitlick, M. A. Madej, and B. L. Barkett (2000), Variability of bed mobility in natural, gravel-bed channels and adjustments to sediment load at local and reach scales, Water Resour. Res., 36, $3743-3755$.

Marcus, W. A., S. C. Ladd, J. A. Stoughton, and J. W. Stock (1995), Pebble counts and the role of user-dependent bias in documenting sediment size distributions, Water Resour. Res., 31, 2625-2631.

Meirovich, L., J. B. Laronne, and I. Reid (1998), The variation of watersurface slope and its significance for bedload transport during floods in gravel-bed streams, J. Hydraul. Res., 36, 147-157.

Milhous, R. T. (1973), Sediment transport in a gravel-bottomed stream, Ph.D. thesis, 232 pp., Oregon State Univ., Corvallis.

Parker, G., and P. C. Klingeman (1982), On why gravel-bed streams are paved, Water Resour. Res., 18, 1409-1423.
Parker, G., P. C. Klingeman, and D. G. McLean (1982), Bed load and size distribution in gravel-bed streams, J. Hydraul. Div. Am. Soc. Civ. Eng., 108, 544-571.

Petit, F. (1994), Dimensionless critical shear stress evaluations from flume experiments using different gravel beds, Earth Surf. Processes Landforms, 19, 565-576.

Powell, D. M., and P. J. Ashworth (1995), Spatial pattern of flow competence and bed load transport in a divided gravel bed river, Water Resour. Res., 31, 741-752.

Powell, D. M., I. Reid, and J. B. Laronne (2001), Evolution of bed load grain size distribution with increasing flow strength and the effect of flow duration on the caliber of bed load sediment yield in ephemeral gravel bed rivers, Water Resour. Res., 37, 1463-1474.

Prestegaard, K. L. (1983), Variables influencing water-surface slopes in gravel-bed streams at bankfull stage, Geol. Soc. Am. Bull., 94, 673-678.

Rantz, S. E., et al. (1982), Measurement and computation of streamflow, volume 1. Measurement of stage and discharge, volume 2. Computation of discharge, U.S. Geol. Surv. Water Supply Pap., 2175, 631 pp.

Reid, I., L. E. Frostick, and J. T. Layman (1985), The incidence and nature of bed load transport during flood flows in coarse-grained alluvial channels, Earth Surf. Processes Landforms, 10, 33-44.

Ryan, S. E., L. S. Porth, and C. A. Troendle (2005), Coarse sediment transport in mountain streams in Colorado and Wyoming, USA, Earth Surf. Processes Landforms, 30, 269-288, doi:10.1002/esp.1128.

Schoklitsch, A. (1962), Handbuch des Wasserbaues, 3rd ed., Springer, Vienna.

Shields, A. (1936), Application of similarity principles and turbulence research to bed-load movement, in Mitteilungen der preussischen Versuchsanstalt für Wasserbau und Schiffbuar, Rep. 167, translated by W. P. Ott and J. C. Unchelen, California Inst. of Tech., Pasadena.

Sterling, S. M., and M. Church (2002), Sediment trapping characteristics of a pit trap and the Helley-Smith sampler in a cobble gravel bed river, Water Resour. Res., 38(8), 1144, doi:10.1029/2000WR000052.

Vericat, D., M. Church, and R. J. Batalla (2006), Bed load bias: Comparison of measurements obtained using two (76 and $152 \mathrm{~mm})$ Helley-Smith samplers in a gravel bed river, Water Resour. Res., 42, W01402, doi:10.1029/2005WR004025.

Whitaker, A. C. (1997), The initiation of coarse bed load transport in gravel bed streams, Ph.D. thesis, 148 pp., Univ. of Montana, Missoula.

Whitaker, A. C., and D. F. Potts (1996), Validation of two threshold models for bedload initiation in an upland gravel-bed stream, paper presented at AWRA Annual Symposium, Watershed Restoration Management: Physical, Biological and Chemical Considerations, Am Water Resour. Assoc., Syracuse, N. Y., July.

Whitaker, A. C., and D. F. Potts (2007), Coarse bed load transport in an alluvial gravel bed stream, Dupuyer Creek, Montana, Earth Surf. Processes Landforms, doi:10.1002/esp.1512, in press.

White, W. R., and T. J. Day (1982), Transport of graded gravel bed material, in Gravel-Bed Rivers, edited by R. D. Hey, J. C. Bathurst, and C. R. Thorne, pp. 181-223, John Wiley, Hoboken, N. J.

Wilcock, P. R. (1988), Methods for estimating the critical shear stress of individual fractions in mixed-sized sediment, Water Resour. Res., 24, $1127-1135$.

Wilcock, P. R. (1992), Flow competence: a criticism of a classic concept, Earth Surf. Processes Landforms, 17, 289-298.

Wilcock, P. R. (2001), Toward a practical method for estimating sedimenttransport rates in gravel-bed rivers, Earth Surf. Processes Landforms, 26, 1395-1408, doi:10.1002/esp.301.

Wilcock, P. R., and B. T. DeTemple (2005), Persistence of armor layers in gravel-bed streams, Geophys. Res. Lett., 32, L08402, doi:10.1029/ 2004GL021772.

Wilcock, P. R., and J. B. Southard (1988), Experimental study of incipient motion in mixed-size sediment, Water Resour. Res., 24, 1137-1151.

Wohl, E. E., D. J. Anthony, S. W. Madsen, and D. M. Thompson (1996), A comparison of surface sampling methods for coarse fluvial sediments, Water Resour. Res., 32, 3219-3226.

Wolman, M. G. (1954), A method of sampling coarse river-bed material, Eos Trans. $A G U, 35,951-956$.

D. F. Potts, College of Forestry and Conservation, University of Montana, Missoula, MT 59812, USA.

A. C. Whitaker, Faculty of Agriculture, Niigata University, 8050 Ikarashi 2-nocho, Niigata 950-2181, Japan. (whitaker@ agr.niigata-u.ac.jp) 